\title{
Tandem Tetrahydroisoquinoline-4-carboxylic Acid/ $\beta$-Alanine as a New Construct Able to Induce a Flexible Turn
}

Raffaella Bucci, ${ }^{\dagger}$ Dr. Andrea Bonetti, ${ }^{[\mathrm{a}]}$ Prof. Francesca Clerici, ${ }^{[\mathrm{a}]}$ Prof. Alessandro Contini, ${ }^{[\mathrm{a}]}$ Donatella Nava,${ }^{[\mathrm{a}]}$ Dr. Sara Pellegrino, ${ }^{[\mathrm{a}]}$ Dr. Davide Tessaro, ${ }^{[\mathrm{b}]}$ Prof. Maria Luisa Gelmi ${ }^{[\mathrm{a}]^{*}}$

${ }^{[a]}$ DISFARM, Sezione di Chimica Generale e Organica “A. Marchesini” Università degli Studi Milano, Via Venezian 21, I-20133 Milano (Italy)

${ }^{[\mathrm{b}]}$ Department of Chemistry, Materials and Chemical Engineering "G. Natta”, Politecnico di Milano, p.za L. da Vinci 32, I-20133 Milano (Italy)

*Maria Luisa Gelmi, full professor, marialuisa.gelmi@unimi.it

\begin{abstract}
Tetrahydroisoquinoline-4-carboxylic acid, a constrained $\beta^{2}$-amino acid named $\beta$-TIC, was for the first time synthesized in enantiopure form. The biocatalytic route here applied represents one of the few successful examples of enzymatic resolution of $\beta^{2}$-amino acids. Model tetrapeptides, i.e. Fmoc-L-Ala- $\beta$-TIC- $\beta$-Ala-L-Val-OBn, containing both isomers of $\beta$-TIC, were prepared. Both computational and NMR studies were performed. A reverse-turn conformation was observed in the case of $R$ - $\beta$-TIC enantiomer that was obtained in $99 \%$ e.e. by enzymatic resolution. $\beta$-TIC/ $\beta$-Ala construct represents the first example of a flexible turn mimetic containing a cyclic and an acyclic $\beta$-amino acid. Furthermore, the presence of an aromatic ring of $\beta$-TIC could facilitate non-covalent interactions increasing the potential of this scaffold for the preparation of protein-protein interaction modulators.
\end{abstract}

\section{Introduction}

It is of general knowledge that peptide shape and conformation influence proteins structure and function. ${ }^{[1]}$ Loops and turns, in particular, acting as linking motifs between different secondary structures, are the molecular tools used to reverse the peptide backbone direction inducing protein tertiary structure. Even if loops are often called random coils, they exhibit a significant amount of regular structural patterns involving polypeptide segments of varying length. ${ }^{[2]}$ Considering the 
enormous variety of sequences that can form such motifs, researches focused on their identification are gaining increasing attention. ${ }^{[2 \mathrm{~b}]}$

Small-molecules capable of mimicking peptide turn structures ${ }^{[3]}$ are particularly useful in validating new drug targets, and in the development of new therapeutics. They are indeed valuable in defining the residues and the secondary structures responsible for the binding recognition and affinity, and, of particular relevance, they can induce an increased stability to proteolysis. One of the most promising applications of turn mimics is addressed to the modulation of protein-protein interactions (PPIs). Turn region is indeed often involved in the protein interaction interface. An important feature to be taken into account when designing PPIs modulators is the flexibility of the proteins. So, their adaptability in the formation of the complex with the protein is of relevance. ${ }^{[4]}$ The use of flexible turn tools that can accommodate themselves to the target in a better way with respect to the rigid turn mimics can represent an effective tool to approach this issue. Another important feature is the type of functional groups of the turn region responsible for PPI. An aromatic residue could be considered a key element in stabilizing the complex through non covalent bonds. ${ }^{[5]}$

The synthesis of non natural amino acids, ${ }^{[6]}$ and of scaffolds to be used as turn-mimics ${ }^{[6, i, 1]}$ as well as their use to prepare peptide model sequences ${ }^{[6-\mathrm{a}, \mathrm{e}]}$ and PPI inhibitors ${ }^{[\mathrm{4a}, 7]}$ is one of our main research fields.

Recently, we envisaged the tetrahydroisoquinoline-4-carboxylic acid (1, Scheme 1), a $\beta^{2}$-amino acid, as a potential turn mimetic satisfying the above requirements. According to the nomenclature reported for the corresponding 3-carboxylic acid, ${ }^{[8]} \mathrm{a} \alpha$-amino acid, we named compound $\mathbf{1} \beta$-TIC. $\beta$-TIC is a very expensive commercially available compound whose preparation in racemic form has already been reported in literature ${ }^{[9]}$ Here, we revisited the synthetic protocol, reducing the synthetic steps, allowing us to obtain ethyl ester of $\mathbf{1}$ in gram scale and excellent yields. Furthermore, we attempted a biocatalytic route leading to the unavailable enantiopure $\beta$-TIC. Biocatalysis is indeed a very efficient tool for performing a chemical resolution in the frame of green chemistry. ${ }^{[10]}$ The obtainment of enantiopure $\beta$-TIC places several issues. First, H- $\alpha$ proton in benzylic position is very acidic, favouring its potential racemization in non-mild conditions. To our knowledge, in contrast with their $\beta^{3}$ homologs, few enzymatic resolutions of $\beta^{2}$-amino acids have been described in literature giving poor results in terms of enantioselectivity and efficiency. ${ }^{[1]}$ More recently, oxazinones were used as suitable precursors for the enzymatic dynamic kinetic resolution of non cyclic $\beta^{2}$-amino acids. ${ }^{[11 b]}$ The most similar analogues on which a kinetic resolution have been carried out, although with scarce success, have been reported in a paper by Kanerva et al. ${ }^{[11 c]}$ Despite these not so encouraging results, we considered it would have be worth attempting an enzymatic resolution, firstly for its simplicity, but also for its potential success. 
Due to the importance of $\beta$-amino acid residues in controlling peptide shape and function, ${ }^{[12]}$ in the second part of our researches, we focused on the use of $\beta$-TIC in combination with $\beta$-alanine, as an effective tool for flexible turn mimics. The use of $\beta$-TIC for the preparation of peptides has been claimed on several patents, although no literature data are reported so far.

Gellman et al. ${ }^{[3 \mathrm{~d}, \mathrm{e}, \mathrm{g}]}$ used the parent nipecotic acid (Nip) as a turn inducer when inserted in $\beta$-peptide sequences as an homo-dipeptide. Curiously, $R$-Nip-S-Nip dipeptide segment or the $S, R$ counterpart, gives $\beta$-peptide reverse-turns that promote the hairpin formation. On the other hand, dipeptides containing Nip in the same stereochemistries are ineffective ${ }^{[3 e]}$ just like when a single Nip unit is matched with an acyclic $\beta$-amino acid. ${ }^{[3 g]}$

In our case, we envisaged that the aromatic part of $\beta$-TIC could induce a further constrain in the dipeptide architecture, better orienting the groups involved in a H-bond. A turn conformation could be stabilized, also in the presence of an acyclic $\beta$-amino acid. The combination of the constrained $\beta$-TIC with the highly conformational flexible $\beta$-alanine might constitute the molecular trick for modulating rigidity and adaptability. ${ }^{[4]}$ This construct provides a simple model system to be used for future applications such as in building peptidomimetics addressed to PPI interaction. As added value, the presence of the aromatic ring could favour non-covalent interactions, as point out before. Finally, the use of the $\beta$-TIC/achiral $\beta$-alanine, instead of two chiral amino acids of opposite conformation, makes easier the synthetic approach of the corresponding turn.

Short model peptide sequences containing both L- $\alpha$-amino acids and $\beta$-amino acids, i.e. the tetrapeptides Fmoc-L-Ala- $\beta$-TIC- $\beta$-Ala-L-ValOBn, were prepared. In order to prove the correlation between the conformation of the peptides and $\beta$-TIC stereochemistry, both $\beta$-TIC-enantiomers were tested. Both computational and spectroscopic studies were performed to prove the ability of $\beta$-TIC$\beta$-Ala construct to generate a turn structure.

\section{Results}

Synthesis of amino acid $\mathbf{1}$ and derivatives. As reported in literature, ${ }^{[9]} \beta$-TIC $\mathbf{1}$ is prepared from 3bromo-isoquinoline in 4 steps and $45 \%$ overall yield. Here we revisited the synthetic procedure, decreasing the synthetic steps, and focusing on the synthesis of ethyl ester of $\beta$-TIC, the key reagent for the enzymatic resolution. Ester 3 (98\%) was directly prepared from 4-bromo-isoquinoline (2) using a recent procedure reported for the corresponding methyl ester, ${ }^{[13]}$ consisting of a carbonylation reaction in the presence of EtOH/TEA, $\mathrm{Pd}(\mathrm{OAc})_{2}$ and xantphos as ligand. The reduction of pyridine ring ${ }^{[14]}$ with $\mathrm{H}_{2}$ in the presence of $\mathrm{Pt}_{2} \mathrm{O}$ in $\mathrm{AcOH}$ gave the expected 
compounds 4 (85\%) (Scheme 1). Amino acid 1 ( $\mathrm{HCl}$ salt, quantitative yield) was obtained by hydrolysis of esters 4 with $6 \mathrm{~N} \mathrm{HCl}\left(100{ }^{\circ} \mathrm{C}, 13 \mathrm{~h}\right.$; Scheme 1$)$.

It should be stressed that, starting from the cheap commercially available 4-bromoisochinoline (2), amino acid 1 was prepared in gram sale $(10 \mathrm{~g})$ in three steps and $83 \%$ overall yield.

The preparation of the Boc-derivative $5(60 \%)$ was achieved starting from 4 by reaction with Bocanhydride (dioxane $/ \mathrm{H}_{2} \mathrm{O} / \mathrm{NaHCO}_{3}, 80{ }^{\circ} \mathrm{C}$ ). The yield of 5 was dramatically increased (96\%) using TEA (2.2 eq.) as the base in $\mathrm{CH}_{2} \mathrm{Cl}_{2}\left(25^{\circ} \mathrm{C}, 26 \mathrm{~h}\right)$ (Scheme 1).<smiles>Brc1cncc2ccccc12</smiles>

2<smiles>CCOC(=O)C1CN(S(=O)(=O)OCc2ccccc2)Cc2ccccc21</smiles>

$( \pm)-5$

\section{CO/EtOH/TEA \\ $\mathrm{Pd}(\mathrm{OAc})_{2}(4 \%)$} xantphos (2\%), $12 \mathrm{~h}$ $98 \%$

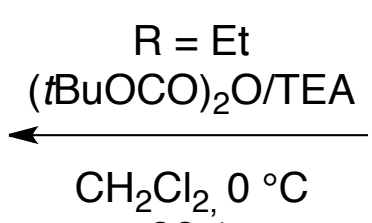<smiles>CCOC(=O)c1cncc2ccccc12</smiles>

3 $\mathrm{H}_{2}, \mathrm{Pt}_{2} \mathrm{O}(10 \%), \mathrm{AcOH}$ $25^{\circ} \mathrm{C}, 1 \mathrm{~atm}$<smiles>O=C(O)C1CNCc2ccccc21</smiles>

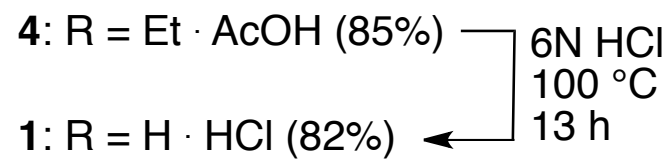

Scheme 1. Synthesis of tetrahydroisoquinoline-4-carboxylic acid derivatives

Enzymatic resolution of $\mathrm{N}-\mathrm{Boc}$ derivative 5. NBoc-protected ethyl ester $\mathbf{5}$ was chosen as the substrate for the enzymatic resolution. This ester was more stable with respect to the corresponding methyl derivative to the spontaneous hydrolysis in the enzymatic resolution conditions (buffer at $\mathrm{pH}$ $8,37^{\circ} \mathrm{C}$ ). Moreover, the hydrogen at $\mathrm{C}-4$ is sufficiently acidic to permit the continuous racemization of the substrate..$^{5]}$ This would give a base for trying to work under dynamic kinetic resolution conditions. ${ }^{[16]}$

An intensive screening involving about 50 commercial hydrolases belonging to various subclasses (esterases, lipases, proteases, peptidases) was carried out (Table TS1 and Figure 1; for details see Supporting Information). Pronase, a mixture of proteases extracted from the extracellular fluid of Streptomyces griseus, proved to be the most convenient catalyst in terms of activity and specificity. It was able to mediate the stereoselective hydrolysis of the precursor with a not outstanding, yet significative, enantioselectivity $(\mathrm{E}=17)$. As a result, it is possible to isolate the slow-reacting enantiomer (i.e. (-)-5) in high enantiomeric purity by pushing the conversion over $65 \%$ (see Figure FS1 in Supporting Information). 


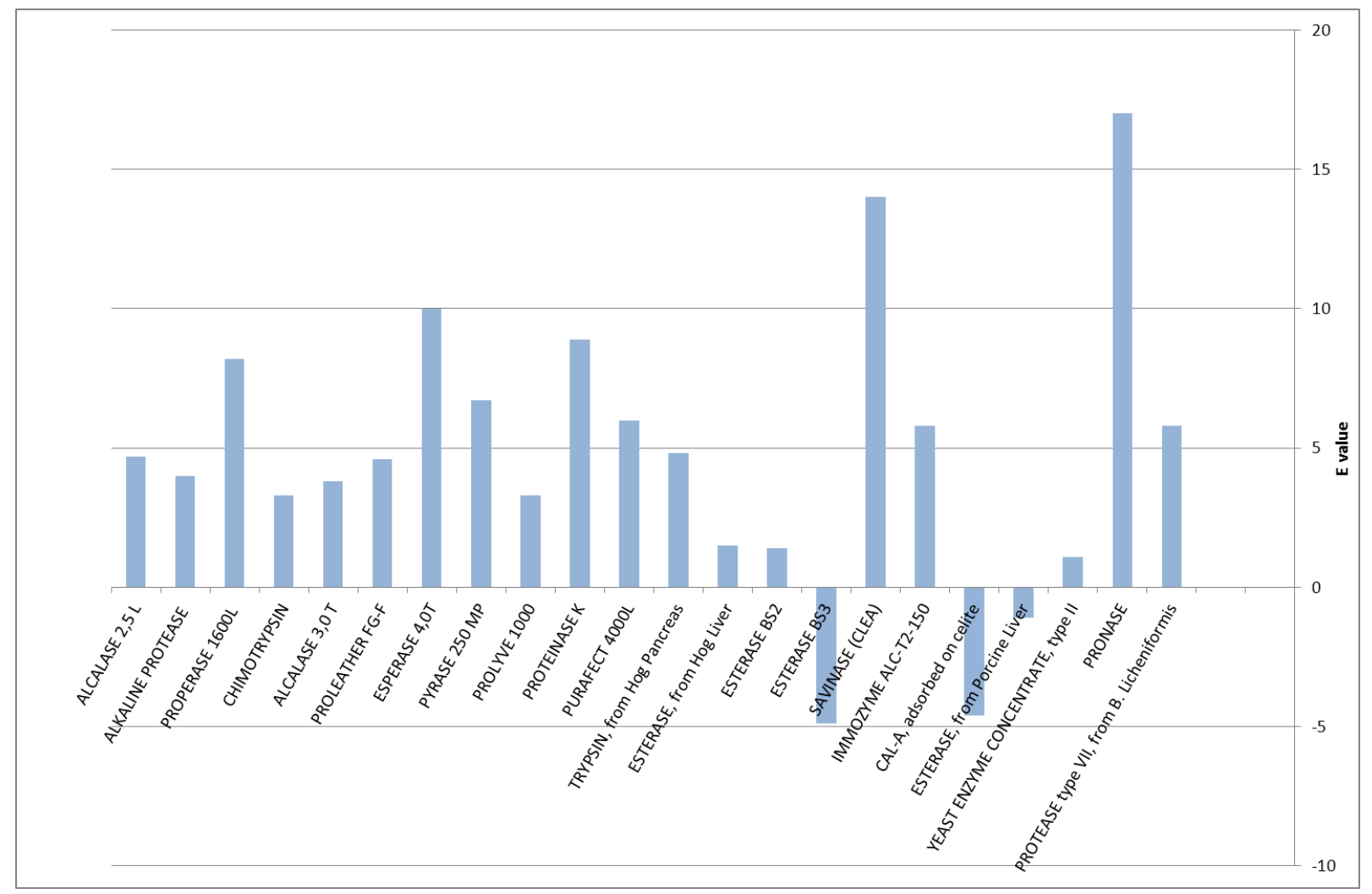

Figure 1. Screening of enzymatic activities on the substrate 5. A negative E value indicates the enzyme preference towards the opposite enantiomer.

The scale up of the enzymatic resolution was performed starting from racemic 5 (1.5 g). The hydrolysis was carried out in a water/DMSO mixture kept at $\mathrm{pH}=8$ by means of an automatic titrator: when the conversion reached about $65-70 \%$, we were able to isolate the starting ester (-)-5 with a very high enantiopurity (e.e. > 99\%) (Scheme 2). Enantio-enriched acid of opposite configuration $(+)-6(e . e . \approx 48 \%)$ was isolated and transformed back into the corresponding ester (+)-5 (DMAP/ $\mathrm{CH}_{2} \mathrm{Cl}_{2} / \mathrm{EtOH}, 0{ }^{\circ} \mathrm{C}$, then DCC; e.e. $\left.\approx 48 \%\right)$. Ester $(+)-5$ was thus recycled as starting material for the successive batch taking advantage of the easiness of the racemization of C-4 in basic conditions (DBU/ $\mathrm{CH}_{2} \mathrm{Cl}_{2} ;$ Scheme 2$)$.

Starting from (-)-5, amino ester (-)-4 TFA was obtained in 100\% yield operating in standard conditions (TFA, $\left.\mathrm{CH}_{2} \mathrm{Cl}_{2}, 0{ }^{\circ} \mathrm{C}, 1 \mathrm{~h}\right)$ (Scheme 2). 

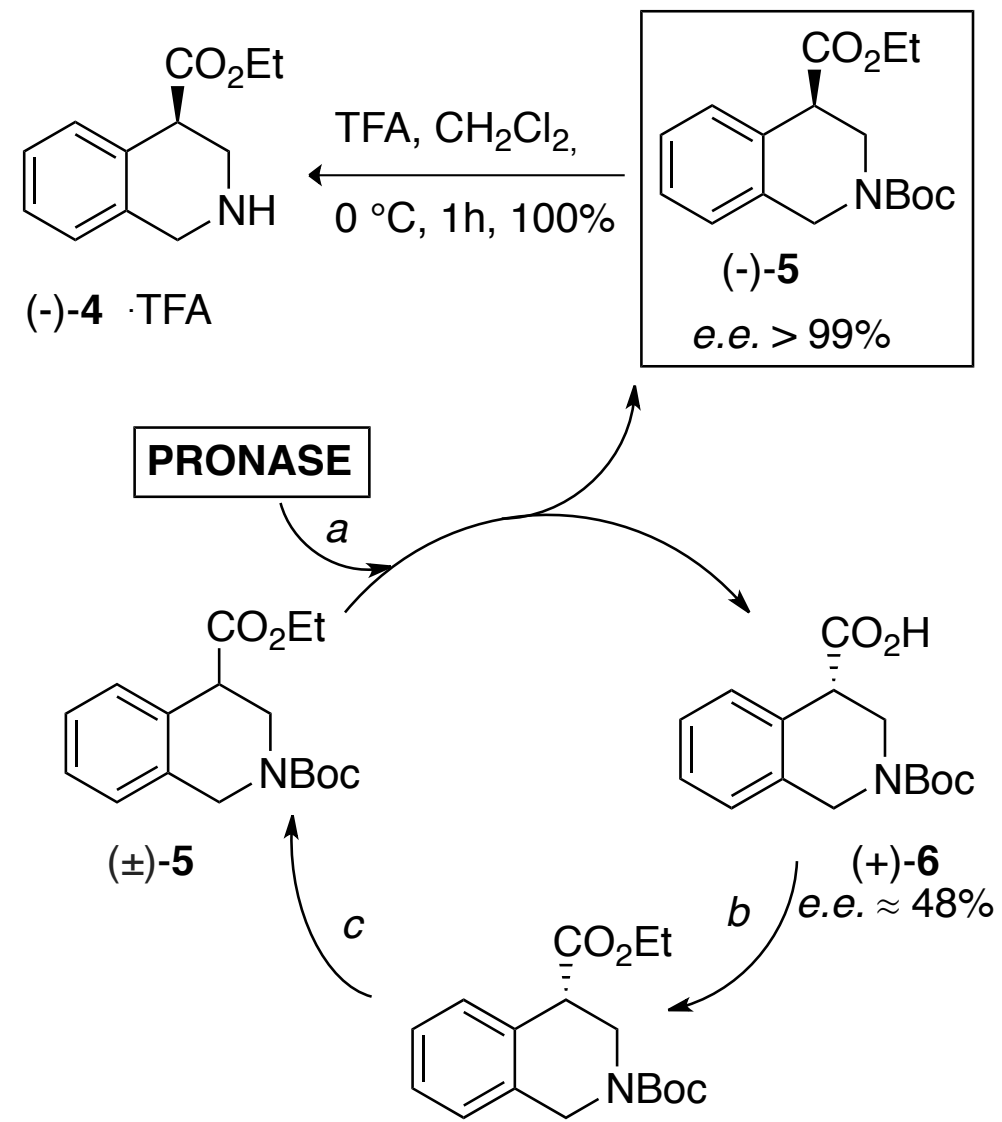

$(+)-5$

e.e. $\approx 48 \%$

Scheme 2. Enzymatic resolution of $\beta$-TIC. a) $40{ }^{\circ} \mathrm{C}$, pH 8, $10 \%$ DMSO; b) DMAP, $\mathrm{CH}_{2} \mathrm{Cl}_{2}$, EtOH, $0{ }^{\circ} \mathrm{C}$, then DCC; c) DBU, $\mathrm{CH}_{2} \mathrm{Cl}_{2}$

Preparation of tetrapeptide models Fmoc-L-Ala- $\beta$-TIC- $\beta$-Ala-L-Val-OBn. In order to evaluate the ability of $\beta$-TIC to induce a turn and to understand the effect of its chirality, two tetrapeptide models, i.e. Fmoc-L-Ala- $\beta$-TIC- $\beta$-Ala-L-Val-OBn, were prepared containing the $R$ - or $S$ - $\beta$-TIC stereoisomer, respectively, (Scheme 3).

The synthesis of dipeptide $\beta$-Ala-L-Val-OBn (7) is not reported in literature. The preparation of 7 from Boc- $\beta$-Ala and $\mathrm{L}-\mathrm{valineOBn} \cdot \mathrm{HCl}$ using a standard protocol [HOBT (1.2 equiv.)/EDC (1.2 equiv.), DIPEA (3 equiv.), $\left.\mathrm{CH}_{2} \mathrm{Cl}_{2}\right]$ gave poor yields due to the formation of a 2,6dioxotetrahydropyrimidine by-product. An increase of the yield of 7 was achieved by transforming first Boc- $\beta$ Ala into its corresponding anhydride $[i \mathrm{BuOCOCl}, N$-methylmorpholine (NMM, 1 equiv.), $\left.\mathrm{CH}_{2} \mathrm{Cl}_{2}, 0{ }^{\circ} \mathrm{C}, 1 \mathrm{~h}\right]$ that was directly coupled with L-valineOBn $\cdot \mathrm{HCl}$ (NMM, 1 equiv.). Boc$\beta$-Ala-L-Val-OBn (84\%) was isolated and deprotected at nitrogen atom (TFA, $\left.\mathrm{CH}_{2} \mathrm{Cl}_{2}, 0{ }^{\circ} \mathrm{C}, 1 \mathrm{~h}\right)$ affording dipeptide 7 (76\%; Scheme SS1).

$\beta$-TIC ester (-)-4 TFA was treated with Fmoc-L-Ala (HOBT/EDC/ $\left.\mathrm{CH}_{2} \mathrm{Cl}_{2}, 25^{\circ} \mathrm{C}, 8 \mathrm{~h}\right)$ giving (-)-8 
in $90 \%$ yields. To avoid the racemization of $\beta$-TIC during the hydrolysis of the ester function, different conditions were tested. The acid (-)-9 (89\%) was successfully obtained without racemization from (-)-8 using $\mathrm{Me}_{3} \mathrm{SnOH}^{[17]}\left(\mathrm{CH}_{2} \mathrm{Cl}_{2}, 50{ }^{\circ} \mathrm{C}, 10 \mathrm{~h}\right)$. The reaction of 9 with $\beta$-Ala-LValOBn (7) (HOBT/EDC, DMF, $\left.25^{\circ} \mathrm{C}, 2 \mathrm{~h}\right)$ gave (+)-10 (71\%). Peptide (+)-10 was obtained in excellent overall yields (57\%) starting from (-)-4.

The whole protocol could be performed from the racemic compound 4, without separation of any intermediate. Tetrapeptides (+)-10 and (-)-11 were obtained in 43\% overall yield and were partially separated by column chromatography.

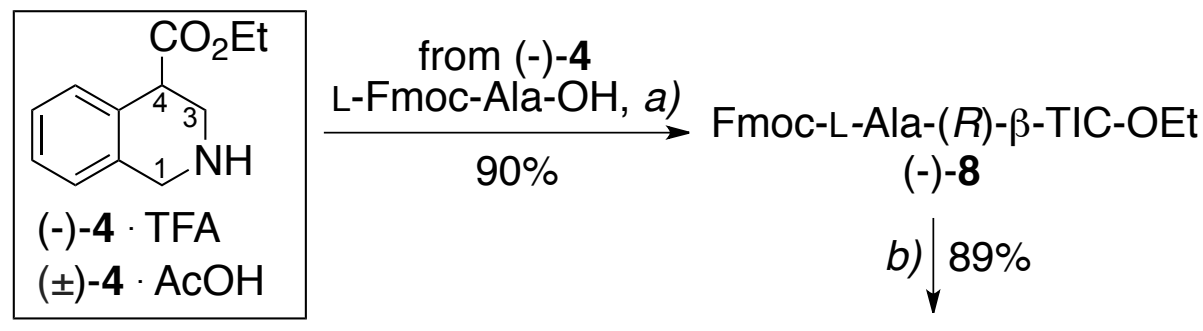

1. Fmoc-L-Ala-OH, a) Fmoc-L-Ala- $(R)-\beta-\mathrm{TIC}-\mathrm{OH}$

2. b) from $( \pm)-4$

3. $\beta$-Ala-L-Val-OBn (7), c)

$(-)-9$

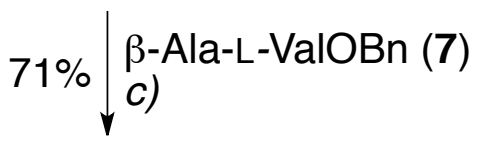

Fmoc-L-Ala-(S)- $\beta$-TIC- $\beta$-Ala-L-Val-OBn $\quad$ Fmoc-L-Ala-(R)- $\beta$-TIC- $\beta$-Ala-L-Val-OBn

$(-)-11$

$(+)-10$

Scheme 3. Synthesis of diastereoisomeric peptides (+)-10 and (-)-11. a) HOBT/EDC, $\mathrm{CH}_{2} \mathrm{Cl}_{2} / \mathrm{DMF}$, $0{ }^{\circ} \mathrm{C}$, then DIPEA, $25{ }^{\circ} \mathrm{C}, 8$ h. b) $\mathrm{Me}_{3} \mathrm{SnOH}, \mathrm{CH}_{2} \mathrm{Cl}_{2}, 50{ }^{\circ} \mathrm{C}, 10$ h.c) HOBT/EDC, DMF, $25{ }^{\circ} \mathrm{C}, 2 \mathrm{~h}$.

NMR peptide characterization. ${ }^{1} \mathrm{H}$ NMR spectra of dipeptides (-)-8 and (-)-9 showed the presence of two conformers (1:1). To confirm the presence of two rotames, studies at variable temperatures were performed for (-)-9 (DMSO- $\left.\mathrm{d}_{6}\right)$ indicating a temperature of coalescence of $50^{\circ} \mathrm{C}$ (Figure FS3).

Both tetrapeptides (+)-10 and (-)-11 were fully characterized by NMR $\left({ }^{1} \mathrm{H},{ }^{13} \mathrm{C}, \mathrm{HMQC}, \mathrm{HMBC}\right.$, TOCSY and ROESY experiments in $\mathrm{CDCl}_{3}, 20 \mathrm{Mm}, 500 \mathrm{MHz}$ ). As reported in Tables TS3-TS6 all resonances were assigned.

${ }^{1} \mathrm{H}$ NMR spectrum of peptides $(+)-\mathbf{1 0}$ showed the presence of two rotamers $(\mathbf{1 0}$ and $\mathbf{1 0}, 1: 1)$ at $\beta$ TIC tertiary amide bond. ${ }^{[3 \mathrm{e}]}$ According to the computational models, a gauche and a staggered conformation are proposed for $\beta$-alanine in $\mathbf{1 0}$ and10', respectively.

All NH signals in both rotamers are well dispersed indicating defined conformations. Furthermore, $\mathrm{NH}$ resonances of the same amino acid in the two rotamers fall in the same region. Valine NHs 
resonate at lower fields ( $\delta 7.88$ and 7.16, respectively) with respect to NHs of $\beta$-Ala ( $\delta 6.62$ and 6.10) and Ala ( $\delta 5.70$ and 5.96).

The solvent titration of the NH chemical shifts was performed (Figure 2). The polar solvent DMSO added to the $\mathrm{CDCl}_{3}$ solution induces similar chemical shift changes in both rotamers. A pronounced downfield shift with increasing concentrations of DMSO was observed for $\mathrm{NH}_{\mathrm{BAla}}\left(\Delta \delta_{\mathrm{NH}}: 0.66\right.$ and 1.02 , respectively) indicating its solvent exposure. The intermediate value for $\mathrm{NH}_{\mathrm{Ala}}\left(\Delta \delta_{\mathrm{NH}}: 0.47\right.$ and 0.69 , respectively) suggests that this $\mathrm{NH}$ is partially solvated. The chemical shift of $\mathrm{NH}_{\mathrm{Val}}$ is insensitive to the solvent $\left(\Delta \delta_{\mathrm{NH}}: 0.14\right.$ and 0.19 , respectively), confirming its shielding from the solvent. This datum, together with its resonance at low field, confirms that $\mathrm{NH}$ of valine is involved in a strong intramolecular hydrogen bond. Comparing the stability of the H-bond network of the two rotamers, it is evident that rotamer $\mathbf{1 0}$ is less sensitive to DMSO with respect to 10', indicating a stronger H-bond stability.

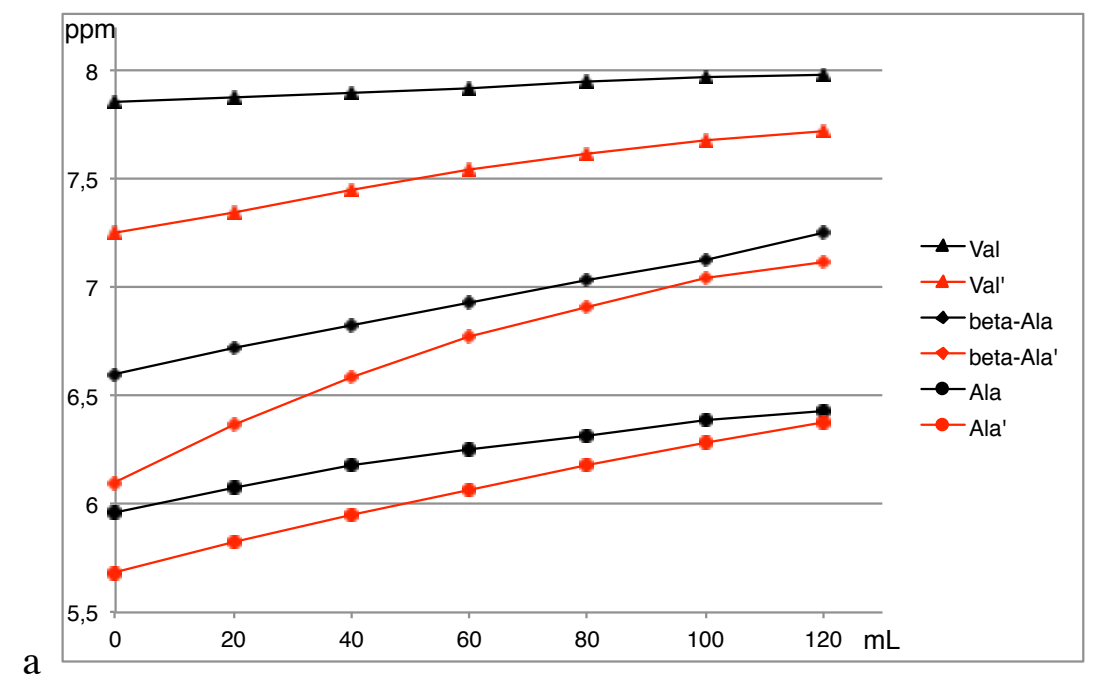

Figure 2. Plots of the $\delta$ NHs in the ${ }^{1} \mathrm{H}$ NMR spectra of (+)-10 as a function of the increasing amount of DMSO added to the $\mathrm{CDCl}_{3}$ solution (v/v) (peptide concentration: $20 \mathrm{mM}$ ). Black: 10; Red: 10'.

NOESY/ROESY experiments (see Tables TS3 and TS4 for detail in SI and Figure 3) at different mixing times (from 100, 200, $300 \mathrm{~ms}$ ) gave interesting information on the secondary structure of peptide (+)-10 (Figures FS4, FS5 and FS6) and, together with $J$ values of the $\beta$-TIC protons, allowed us to assign the $R$-stereochemistry to $\beta$-TIC (see Supporting Information for discussion). 
According to the ROEs (Figure 3) and the computational models, it was possible to assign unequivocally the pro- $R$ and pro-S chemical shifts to methylene groups of $\beta$-alanine of both conformer $\mathbf{1 0}$ and 10'.

A significant ROE for rotamer 10, supporting the formation of a turn, is that of H-3 $3_{\text {B-TIC }}$ in equatorial position with $\mathrm{NH}_{\mathrm{Val}}($ Figure 4A). As shown in Figure 4B, a very week ROE was detected between H- $3_{\text {pro-s }}$ of $\beta$-ALA and H- $3_{\text {r-TIC }}$ in axial position. According to the computational models (see below), this ROE is not consistent with conformer 10, neither with 10', but it is probably due to a transition conformation between 10/10'. Both $\mathrm{CH}_{\mathrm{Ala}}$ and $\mathrm{Me}_{\mathrm{Ala}}$ showed proximity with $\mathrm{H}-1_{\text {s-TIC }}$ (Figure $4 \mathrm{C}$ ) confirming that the carbonyl function of Ala is oriented inside the turn ( $E$ rotamer). Furthermore, a complete set of $\mathrm{CH} / \mathrm{NH}(\mathrm{i}, \mathrm{i}+1)$ is present (Figure FS5).

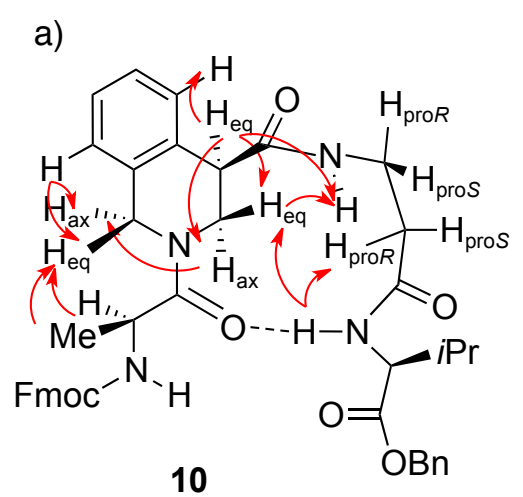

c)

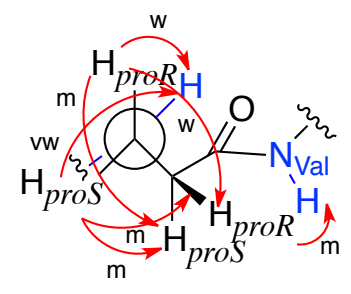

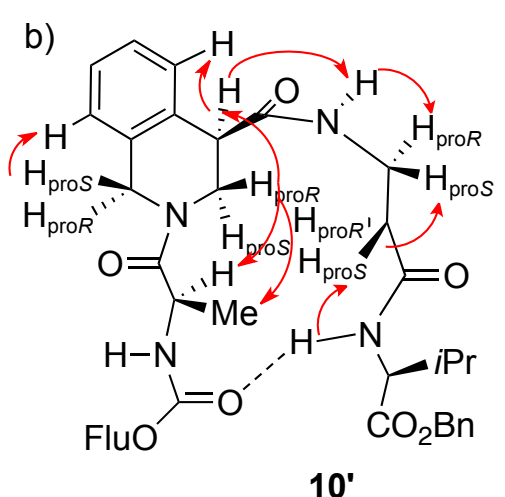

d)

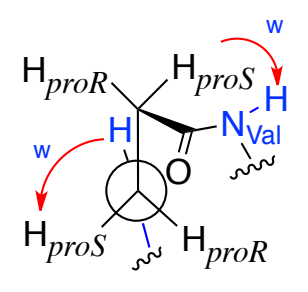

Figure 3. Proposed conformation for rotamers 10 (a) and 10' (b). Zoom of the $\beta$-alanine moiety for 10 (c) and 10' (d). Dotted lines: H-bond; Arrow: spatial proximities.

Rotamer 10' (Figure 3) does not present intrastrand NOEs and showed spatial proximity between $\mathrm{H}-\alpha$ and $\mathrm{Me}$ of alanine with $\mathrm{H}-3_{\mathrm{B}-\mathrm{TIC}}$, confirming the presence of the Z-rotamer at tertiary amide (Figures 4D and FS 6). 

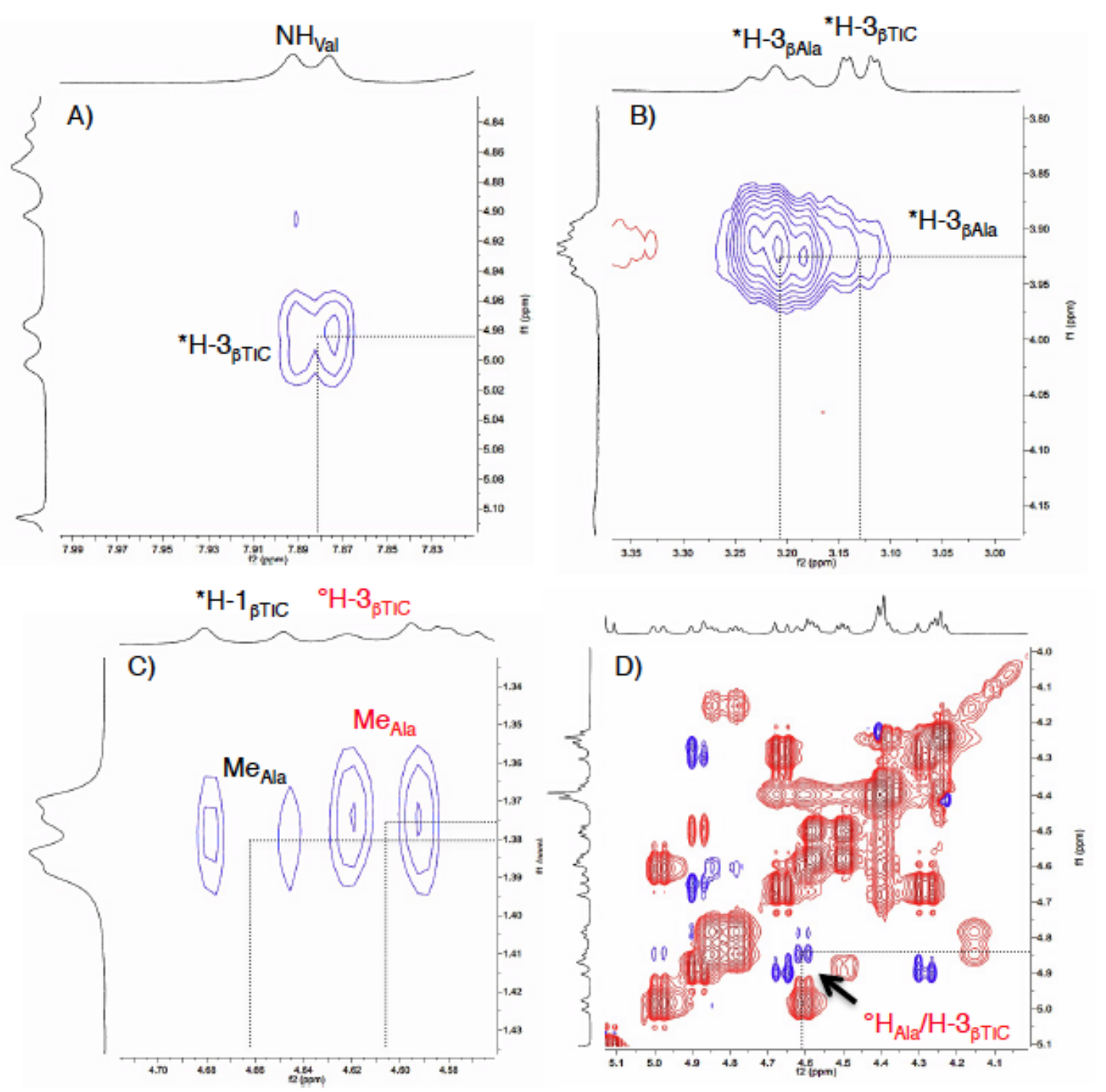

Figure 4. Zoom of significant ROEs to define turn structures of peptide (+)-10 $\left(\mathrm{CDCl}_{3}, 20 \mathrm{mM}\right)$ : *black: 10; ${ }^{\circ}$ red: 10’. A), B), D: $200 \mathrm{~ms}$, C) $100 \mathrm{~ms}$.

Taken together these data confirm that peptide $(+)-\mathbf{1 0}$, containing $(R)-\beta$-TIC enantiomer, gave two turn conformations that are in equilibrium. (Figure 3). The formation of a strong H-bond between $\mathrm{C}=\mathrm{O}$ of alanine with $\mathrm{NH}_{\mathrm{Val}}$ (12-membered ring) is proposed for the $E$-rotamer 10. The intermediate $\Delta \delta_{\mathrm{NH}}$ value of $\mathrm{NH}_{\mathrm{Ala}}$ found in titration experiment suggests that an equilibrium between a $\mathrm{H}$-bonded and not-bonded could occur between $\mathrm{NH}_{\mathrm{Ala}}$ and $\mathrm{C}=\mathrm{O}$ of valine. On the other hand, the Z-rotamer 10' forms a strong $\mathrm{H}$-bond between $\mathrm{NH}_{\mathrm{Val}}$ and $\mathrm{C}=\mathrm{O}$ of the Fmoc group. In this case a bigger turn (15membered ring) was formed (Figure 3).

Peptide (-)-11, containing $S$ - $\beta$-TIC, is present as a mixture of three conformers in a 1:0.6:0.1 ratio. Only the two main isomers, named $\mathbf{1 1}$ and 11', were fully characterized (Tables TS5 and TS6). Differently from (+)-10, NH signals are not dispersed and the DMSO titration gave $\Delta \delta_{\mathrm{NH}}$ values 
larger then 0.7, except for $\mathrm{NH}_{\mathrm{Val}}\left(\Delta \delta_{\mathrm{NH}} 0.5\right)$ (Figure FS10). A complete set of $\mathrm{CH} / \mathrm{NH}(\mathrm{i}, \mathrm{i}+1)$ ROEs were detected exclusively at C-termini arm for 11' (Figures FS7 and FS8). Me $_{\text {Ala }}$ shows spatial proximity with $\mathrm{H}-1_{\text {r-TIC }}$ in both conformers (11, m; 11', w; Figure FS9). These data support the formation of $E$-rotamers. In both cases, intrastrand ROEs are absent. These data indicate that all the isomers of peptide (-)-11 did not assume a preferred conformation.

Based on NOE data, a computational refinement of $\mathbf{1 0}$ and 10' structures was attempted by mean of molecular dynamic (MD) simulations. Distance restraints derived from NMR experiments (see Experimental), shown in Table 1, were used to drive a Simulated Annealing (SA) experiments consisting in a quick heating phase followed by a slow cooling phase.

Table 1. NOE Distances Used to Generate Restraints for Simulated Annealing Calculations.

\begin{tabular}{|c|c|c|c|c|c|}
\hline \multicolumn{3}{|c|}{10} & \multicolumn{3}{|c|}{ 10' } \\
\hline Atom1 & Atom2 & Distance $(\AA)^{a}$ & Atom1 & Atom2 & Distance $(\AA)^{a}$ \\
\hline $\mathrm{Me}_{\mathrm{Ala}}$ & $\mathrm{H} 1_{\beta \mathrm{TIC}}$ & $3.03 \pm 0.22$ & $\mathrm{Me}_{\mathrm{Ala}}$ & $\mathrm{H} 3_{\beta T I C}$ & $3.03 \pm 0.22$ \\
\hline $\mathrm{CH}_{\mathrm{Ala}}$ & $\mathrm{H} 1_{\beta \mathrm{TIC}}$ & $2.49 \pm 0.18$ & $\mathrm{CH}_{\text {Ala }}$ & $\mathrm{H} 3_{\beta T I C}$ & $2.13 \pm 0.04$ \\
\hline $\mathrm{H} 8_{\beta T I C}$ & $\mathrm{H} 1_{\beta \mathrm{TIC}}$ & $2.58 \pm 0.04$ & $\mathrm{H} 4_{\beta \text { TIC }}$ & $\mathrm{H} 3_{\beta T I C}$ & $2.18 \pm 0.03$ \\
\hline $\mathrm{H} 1_{\beta \text { TIC }}^{\prime}$ & $\mathrm{H} 8_{\beta \mathrm{TIC}}$ & $2.56 \pm 0.04$ & $\mathrm{H} 4_{\beta \mathrm{TIC}}$ & $\mathrm{H} 5_{\beta T I C}$ & $2.47 \pm 0.05$ \\
\hline $\mathrm{H} 1^{\prime}{ }_{\beta \text { TIC }}$ & $\mathrm{H} 3{ }^{\prime}{ }_{\beta T I C}$ & $2.68 \pm 0.04$ & $\mathrm{H} 4_{\beta \mathrm{TIC}}$ & $\mathrm{NH}_{\beta \text { Ala }}$ & $2.76 \pm 0.13$ \\
\hline H3' ${ }_{\beta \text { TIC }}$ & $\mathrm{H} 4_{\beta \mathrm{TIC}}$ & $3.2 \pm 0.12$ & $\mathrm{H} 2_{\beta \text { Ala }}$ & $\mathrm{NH}_{\text {Val }}$ & $2.66 \pm 0.02$ \\
\hline $\mathrm{H} 3_{\beta T I C}$ & $\mathrm{H} 4_{\beta \mathrm{TIC}}$ & $2.50 \pm 0.02$ & & & \\
\hline $\mathrm{H} 3_{\beta T I C}$ & $\mathrm{NH}_{\beta \mathrm{Ala}}$ & $2.91 \pm 0.10$ & & & \\
\hline $\mathrm{H} 3_{\beta T I C}$ & $\mathrm{NH}_{\mathrm{Val}}$ & $2.85 \pm 0.11$ & & & \\
\hline $\mathrm{H} 4_{\beta T I C}$ & $\mathrm{H} 5_{\beta \mathrm{TIC}}$ & $2.32 \pm 0.03$ & & & \\
\hline $\mathrm{H} 4_{\beta T I C}$ & $\mathrm{NH}_{\beta \text { Ala }}$ & $2.46 \pm 0.03$ & & & \\
\hline $\mathrm{NH}_{\beta \mathrm{Ala}}$ & $\mathrm{H} 2_{\beta A l a}$ & $2.63 \pm 0.03$ & & & \\
\hline
\end{tabular}

${ }^{a}$ Average of two determinations

The simulation was repeated three times starting from randomly chosen conformations, and full convergence was observed. The final geometries obtained from the SA using the restraint set derived from the NOE of conformers $\mathbf{1 0}$ and 10' are depicted in Figure 5. 

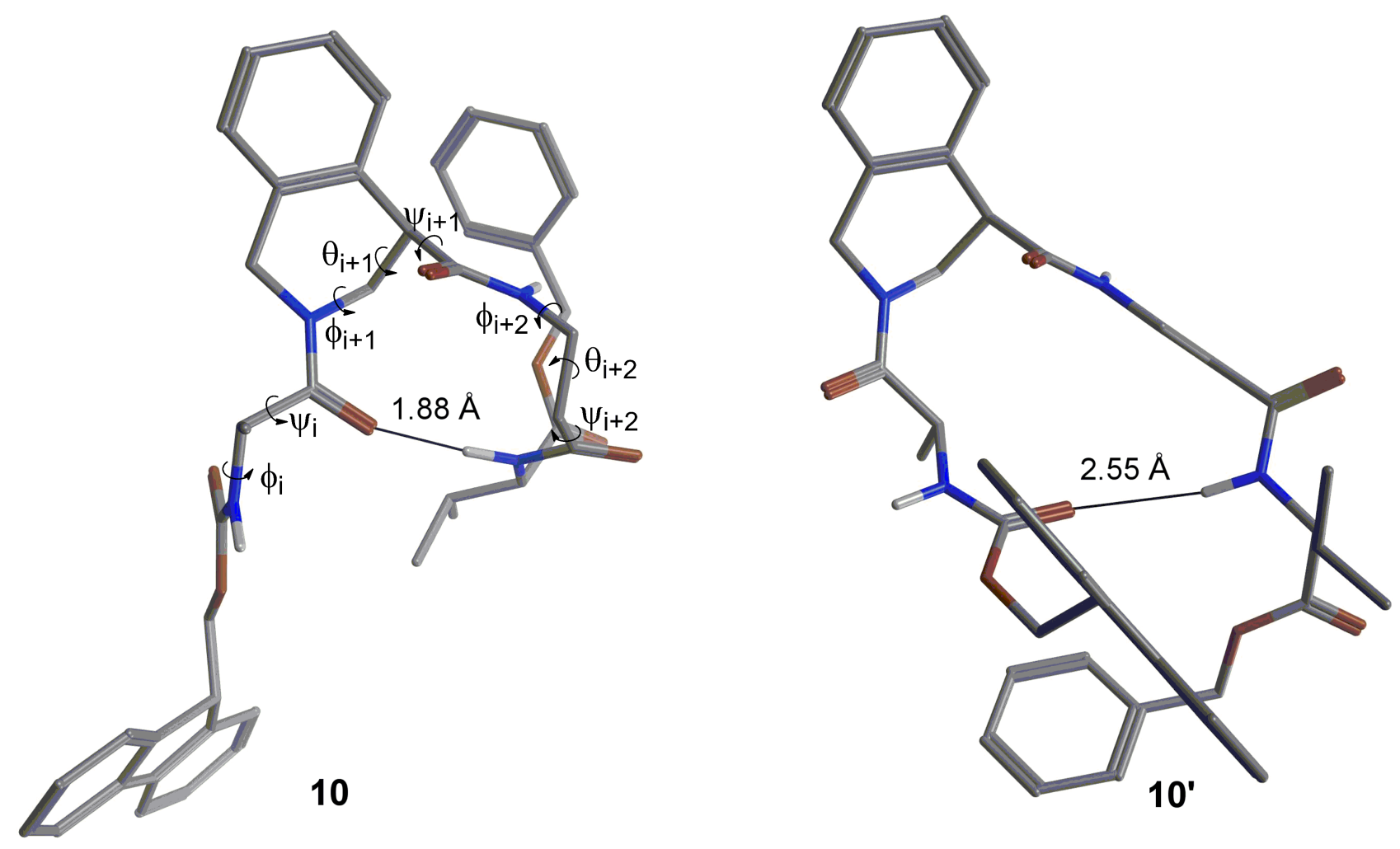

Figure 5. Structures of $\mathbf{1 0}$ and 10' obtained by restrained MD simulated annealing

Table 2. Principal geometrical parameters of $\mathbf{1 0}$ and 10' geometries from restrained SA calculations

\begin{tabular}{|l|l|l|}
\hline Dihedral & \multicolumn{2}{|l|}{ Dihedral value (deg.) } \\
\hline & $\mathbf{1 0}$ & $\mathbf{1 0}$ \\
\hline $\boldsymbol{\varphi}_{\mathbf{i}}$ & -63.9 & -143.4 \\
\hline $\boldsymbol{\psi}_{\mathbf{i}}$ & 140.5 & 145.5 \\
\hline $\boldsymbol{\varphi}_{\mathbf{i}+\mathbf{1}}$ & -109.7 & -112.5 \\
\hline $\boldsymbol{\theta}_{\mathbf{i}+\mathbf{1}}$ & 68.0 & 71.5 \\
\hline $\boldsymbol{\Psi}_{\mathbf{i}+\mathbf{1}}$ & 84.1 & 82.6 \\
\hline $\boldsymbol{\varphi}_{\mathbf{i}+\mathbf{2}}$ & 90.1 & 171.2 \\
\hline $\boldsymbol{\theta}_{\mathbf{i}+\mathbf{2}}$ & 65.9 & 178.8 \\
\hline $\boldsymbol{\Psi}_{\mathbf{i}+\mathbf{2}}$ & -103.5 & 83.5 \\
\hline
\end{tabular}

Both 10 and 10' structures fit well with the geometries proposed in Figure 3 and can be considered as models of peptide turns. Conformation $\mathbf{1 0}$ is characterized by a peptide bond between Ala1 and $\beta$-TIC in pseudo-cis configuration. Indeed, the Ala1 $\mathrm{C}=\mathrm{O}$ points "inward" with respect to the turn curvature and is involved in a rather strong $\mathrm{H}$-bond with Val4 $\mathrm{NH}(\mathrm{O} \cdots \mathrm{H}$ distance $=1.88 \AA)$ making this turn rather similar to a type II $\beta$-turn. Conversely, in conformation 10' the Ala1- $\beta$-TIC peptide bond is in pseudo-trans configuration and an H-bond can be observed between the Fmoc-carbonyl 
and Val4 NH. Selected torsional angles, reported in Table 2, show that the $\beta$-TIC geometry is rather similar in both conformations. Principal differences in the turn core, in addition to the configuration of the Ala1- $\beta$-TIC peptide bond, are found in the $\beta$-Ala dihedrals $\left(\varphi_{i+2}, \theta_{i+2}\right.$ and $\left.\psi_{i+2}\right)$. Indeed, a gauche conformation is observed for the two $\beta$-Ala methylene groups in $\mathbf{1 0}$, in accordance with experimental data, while a staggered conformation (corresponding to a fully extended backbone) is found for 10'.

Another important difference between the two conformations is observed for the benzyloxy protected Val that terminates the turn core. Indeed, in conformer $\mathbf{1 0}$ the benzyl group is oriented toward the $\beta$-TIC scaffold, while in 10' it points toward the Fmoc (fluorene moiety). It is possible that turn conformations are stabilized by the hydrophobic collapse of aromatic rings in polar solvents.

To evaluate the degree of such a contribution, we performed Replica Exchange Molecular Dynamics (REMD) simulations on peptide $\mathbf{1 0}$ and on model peptide $\mathbf{m 1 0}$, differing from the former in the nature of protecting groups [acetyl and NHMe (m10) instead of Fmoc and OBn (10)].

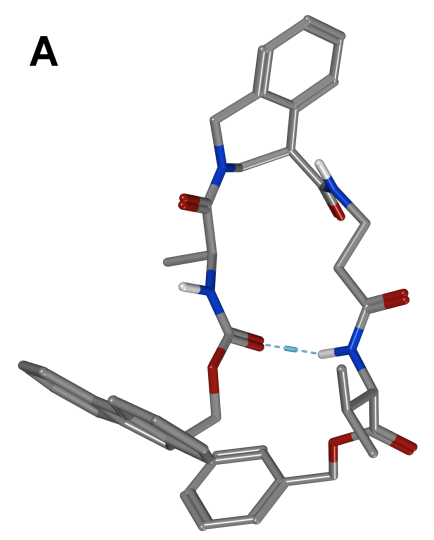

\#1 pop=44.8\%

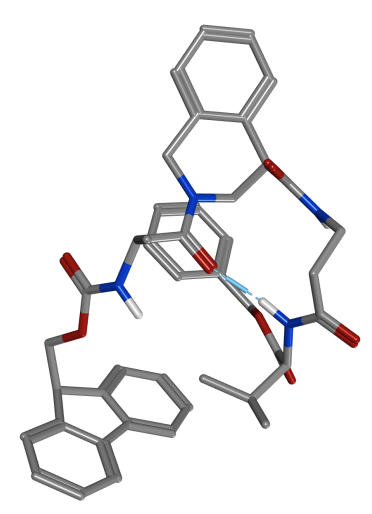

\#2 pop=19.4\%

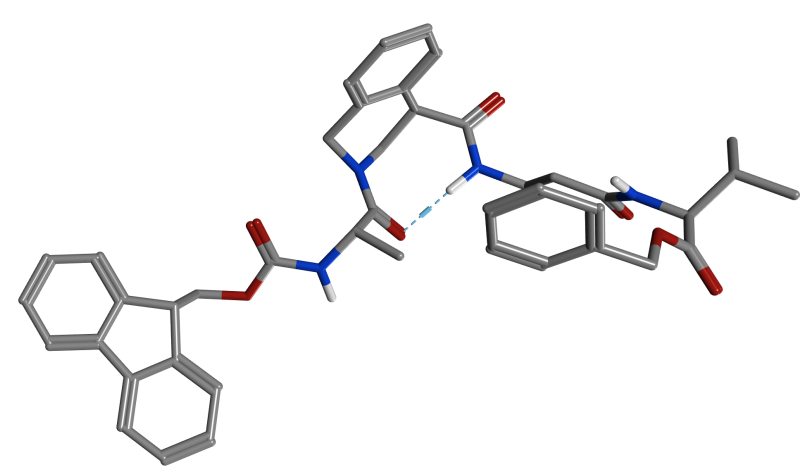

\#3 pop=11.9\%

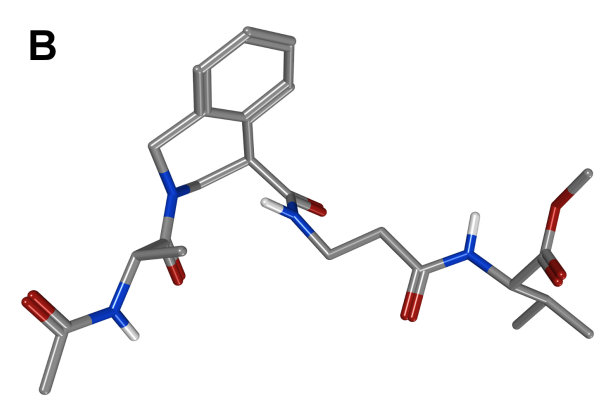

\#1 pop=41.4\%

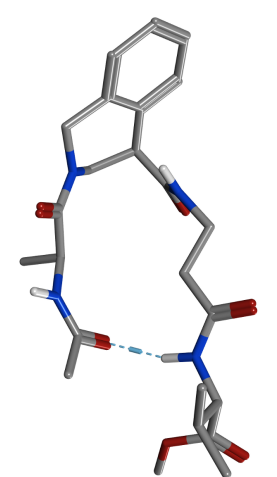

\#2 pop=20.2\%

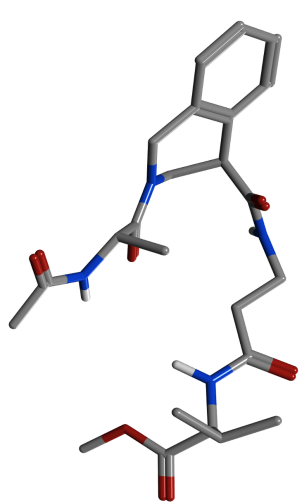

$\# 3$ pop=17.1\%

Figure 6. Comparison of most representative conformations of peptide $\mathbf{1 0}$ (A) and the model peptide $\mathbf{m 1 0}(\mathrm{B})$, obtained from REMD simulations. 
Representative geometries obtained from the cluster analysis of the REMD trajectory at about 300 $\mathrm{K}$ are shown in Figure 6, together with the populations of the corresponding conformational cluster. First of all, it can be observed that the two principal geometries of peptide $\mathbf{1 0}$ (\#1 and \#2, Figure 6, panel A) matches those obtained by the computational refinement of NMR, even if geometry \#1, which resembles conformation 10', resulted the most abundant. This might be due to the use of a solvent model for water, as acetonitrile cannot be simulated by the Generalized Born solvent model implemented in Amber. ${ }^{[18,19]}$ However, since both conformation are well represented, we can consider the results of the simulation sufficiently accurate for our purpose. Geometry \#3 (Figure 6, panel A) represents about the $12 \%$ of the conformational population and is characterized by a $\gamma$ turn involving $\beta$-TIC and $\beta$-alanine.

Considering model $\mathbf{m 1 0}$ (Figure 6, panel B), similar geometries were obtained, but with an inverted stability order. Indeed, the most abundant conformation of $\mathbf{m 1 0}$ is comparable to conformation \#3 of peptide 10. Conversely, the turn conformation \#2 of $\mathbf{m 1 0}$ is superimposable to conformation \#1 of $\mathbf{1 0}$ with a root mean squared displacement (RMSD) of $0.05 \AA$, calculated on $\alpha$ carbons, meaning that the two geometries are identical.

In conclusion, computational results suggest that $\beta$-TIC/ $\beta$-Ala is intrinsically able to stabilize a turn conformation whose type is influenced by the $\mathrm{N}$ - and C-protecting groups.

\section{Conclusion}

The synthesis of $\beta$-TIC 1 was revisited affording the ester 4 in gram scale $(10 \mathrm{~g})$ and excellent overall yields. The enzymatic kinetic resolution of 4 was performed in gram scale too (1.5 g), representing one of the few successful examples of enzymatic resolution of $\beta^{2}$-amino acids. Furthermore, this allowed an enantiopure material ( $R$ isomer: e.e. $>99 \%$ ) to be provided for the first time. This has been employed in the synthesis of the target peptide 10. The racemization of the enantio-enriched $S$-isomer was achieved in order to recycle the material and improve the yield in the view of a possible scale-up. Finally, $R$ - $\beta$-TIC is the right stereoisomer providing a peptide reverse-turn when linked to $\beta$-alanine, as demonstrated by computational and NMR studies for tetrapeptide model Fmoc-L-Ala- $(R)-\beta$-TIC $-\beta$-Ala-L-Val-OBn.

\section{Experimental Section}

Ethyl isoquinoline-4-carboxylate (3). Compound 3 was prepared according to the known procedure, used for the methyl ester, ${ }^{13}$ starting from 4-bromo-isoquinoline (2) (10 g, $\left.48 \mathrm{mmol}\right)$ in the presence of EtOH $(70 \mathrm{~mL})$, TEA $(70 \mathrm{~mL}), \mathrm{Pd}(\mathrm{OAc})_{2}(430 \mathrm{mg}, 1.96 \mathrm{mmol})$ and xantphos $(555$ 
mg, $0.96 \mathrm{mmol})$ under CO atmosphere. Pure ethyl ester $\mathbf{3 b}(9.5 \mathrm{~g}, 98 \%)$ was obtained after column chromatography on silica gel (nhexane/AcOEt, 1:0 to 0:1). M.p. $48{ }^{\circ} \mathrm{C}\left(\mathrm{MeOH} / \mathrm{Et}_{2} \mathrm{O}\right) ;{ }^{1} \mathrm{H}$ NMR $\left(\mathrm{CDCl}_{3}, 200 \mathrm{MHz}\right): \delta=9.37(\mathrm{~s}, 1 \mathrm{H}), 9.18(\mathrm{~s}, 1 \mathrm{H}), 8.34(\mathrm{~d}, J 8.4 \mathrm{~Hz}, 1 \mathrm{H}), 8.03(\mathrm{~d}, J=8.1 \mathrm{~Hz}, 1 \mathrm{H})$, $7.84(\mathrm{t}, J 7.0 \mathrm{~Hz}, 1 \mathrm{H}), 7.67(\mathrm{t}, J 7.0 \mathrm{~Hz}, 1 \mathrm{H}) 4.50(\mathrm{q}, J 7.3,2 \mathrm{H}), 1.48(\mathrm{t}, J 7.3,3 \mathrm{H}) ;{ }^{13} \mathrm{C} \mathrm{NMR}$ $\left(\mathrm{CDCl}_{3}, 300 \mathrm{MHz}\right): \delta=14.5,61.5,120.9,125.3,127.8,128.4,128.7,132.4,134.1,147.0,157.0$, 166.7; MS (ESI): $m / z(\%): 202.1[\mathrm{M}+1]^{+}$; elemental analysis calcd (\%) for $\mathrm{C}_{12} \mathrm{H}_{11} \mathrm{NO}_{2}: \mathrm{C}, 71.63 ; \mathrm{H}$, 5.51; N, 6.96; found C, 71.47; H, 5.63; N, 6.67.

Ethyl 1,2,3,4-tetrahydroisoquinolin-4-carboxylate $\cdot \mathrm{AcOH}$ (4). In a round bottomed flask $\mathrm{Pt}_{2} \mathrm{O}(1$ $\mathrm{g}, 4.41 \mathrm{mmol})$ was suspended in acetic acid $(45 \mathrm{~mL})$. The solution was stirred under $\mathrm{H}_{2}$ atmosphere for $15 \mathrm{~min}$. and then the isoquinoline-4-carboxylate $\mathbf{3}(8.8 \mathrm{~g}, 44 \mathrm{mmol})$ was added. The mixture was stirred under $\mathrm{H}_{2}$ atmosphere at $25{ }^{\circ} \mathrm{C}$ for $24 \mathrm{~h}$. After filtration over a celite plug, the solvent was removed under reduce pressure. The crude mixture was purified by column chromatography $\left(\mathrm{CH}_{2} \mathrm{Cl}_{2} / \mathrm{MeOH}\right.$, from 80:1 to 40:1) giving pure compound 4 as a pale yellow oil $(9.9 \mathrm{~g}, 85 \%) .{ }^{1} \mathrm{H}$ NMR $\left(\mathrm{CDCl}_{3}, 200 \mathrm{MHz}\right): \delta=7.64$ (s, 2H, exch.), 7.33-7.04 (m, 4H), $4.16(\mathrm{q}, J 7.3 \mathrm{~Hz}, 2 \mathrm{H}), 4.07$ (s, 2H), 3.73, 3.55, 3.15 (ABX system, J 13.6, 4.8, 2.9 Hz, 3H), 1.97 (s, 3H), 1.24 (t, J 7.3 Hz, 3H); ${ }^{13} \mathrm{C} \mathrm{NMR}\left(\mathrm{CDCl}_{3}, 500 \mathrm{MHz}\right): \delta=14.3,22.2,42.1,44.6,46.2,61.6,126.8,127.0,127.9,129.8$, 130.6, 134.2, 173.6, 176.1; IR (NaCl) $v_{\max }=3400,1728 \mathrm{~cm}^{-1}$; MS (ESI): $\mathrm{m} / z(\%): 206.2[\mathrm{M}+1]^{+}$; elemental analysis calcd (\%) for $\mathrm{C}_{14} \mathrm{H}_{19} \mathrm{NO}_{4}: \mathrm{C}, 63.38 ; \mathrm{H}, 7.22 ; \mathrm{N}, 5.28$; found $\mathrm{C}, 69.92 ; \mathrm{H}, 7.56 ; \mathrm{N}$, 4.87 .

1,2,3,4-Tetrahydroisoquinoline-2-carboxylic Acid $\mathbf{H C l}$ (1). Operating in a sealed tube, compound $4(11 \mathrm{~g}, 41 \mathrm{mmol})$ was suspended in $\mathrm{HCl}(6 \mathrm{~N}, 25 \mathrm{~mL})$ and the mixture was heated at $120^{\circ} \mathrm{C}$ for $9 \mathrm{~h}$. The solvent was removed under reduced pressure and the residue was crystallized affording pure 1 (8.8 g, quantitative yield). Mp $237{ }^{\circ} \mathrm{C}\left(\mathrm{MeOH} / \mathrm{Et}_{2} \mathrm{O}\right) ;{ }^{1} \mathrm{H}$ NMR (DMSO-d 6,200 MHz) $\delta=11.0-8.5$ (brs, 3H), 7.21-7.45 (m, 4H), 4.23 (s, 2H), 4.10 (t, J 5.5 Hz, 1H), 3.14-3.61 (m, $2 \mathrm{H}) ;{ }^{13} \mathrm{C}$ NMR (DMSO-d 6 , $\left.50 \mathrm{MHz}\right) \delta=41.1$, 42.7, 44.2, 127.7, 128.2, 128.3, 129.6, 129.8, 130.3, 173.2; IR (KBr) $v_{\max } 3030,1725,1609 \mathrm{~cm}^{-1}$; MS (ESI): $m / z(\%): 178.1[\mathrm{M}+1]^{+}$; elemental analysis calcd (\%) for $\mathrm{C}_{10} \mathrm{H}_{12} \mathrm{ClNO}_{2}$ : C, 56.21; H, 5.66; N 6.56; found C, 55.83; H, 5.85, N, 6.02.

Ethyl $N$-Boc-1,2,3,4-tetrahydroisoquinolin-4-carboxylate (5). In a three necked round bottom flask equipped with a magnetic stirrer, nitrogen inlet, and thermometer, compound 4 (3 g, 11.3 mmol) was dissolved in dry $\mathrm{CH}_{2} \mathrm{Cl}_{2}(15 \mathrm{~mL})$ and the solution was cooled to $0{ }^{\circ} \mathrm{C}$. Triethylamine (5.1 mL, $32.2 \mathrm{mmol})$ was added. After $10 \mathrm{~min}$., di-tert-butyl dicarbonate $(3.8 \mathrm{~g}, 17.5 \mathrm{mmol})$ was slowly added and the stirring was continued for $2 \mathrm{~h}$ at $25^{\circ} \mathrm{C}$. The reaction mixture was washed with $\mathrm{KHSO}_{4}(\mathrm{pH}=3,0.5 \mathrm{~N}, 5 \mathrm{~mL})$ and then dried over $\mathrm{Na}_{2} \mathrm{SO}_{4}$. The solvent was removed under reduced pressure and product 5 was obtained as a colourless oil $(4.5 \mathrm{~g}, 96 \%) .{ }^{1} \mathrm{H} \mathrm{NMR}\left(\mathrm{CDCl}_{3}, 200 \mathrm{MHz}\right)$ : $\delta$ 
= 7.27-7.12 (m, 4H), 4.73, $4.48(\mathrm{AB}$ system, $J 17.2 \mathrm{~Hz}, 2 \mathrm{H}), 4.24,3.81,3.59$ (ABX system, $J$ 13.2, $5.1,4.4 \mathrm{~Hz}, 3 \mathrm{H}), 4.17(\mathrm{q}, J 7.0 \mathrm{~Hz}, 2 \mathrm{H}), 1.48(\mathrm{~s}, 9 \mathrm{H}), 1.25(\mathrm{t}, J 7.0,3 \mathrm{H}) ;{ }^{13} \mathrm{C} \mathrm{NMR}\left(\mathrm{CDCl}_{3}, 200\right.$ MHz): $\delta=14.4,28.6$ (x3), 44.1, 45.1, 46.0, 61.3, 80.3, 126.7 (x2), 127.7, 129.1, 131.9, 133.9, 154.9, 172.2; IR (NaCl) $v_{\max }=1736,1699 \mathrm{~cm}^{-1}$; MS (ESI): $\mathrm{m} / z(\%): 328.2[\mathrm{M}+\mathrm{Na}]^{+}$; elemental analysis calcd (\%) for $\mathrm{C}_{17} \mathrm{H}_{23} \mathrm{NO}_{4}: \mathrm{C}, 66.86 ; \mathrm{H}, 7.59 ; \mathrm{N}, 4.59$; found $\mathrm{C}, 66.58 ; \mathrm{H}, 7.80 ; \mathrm{N}, 4.43$.

Enzymatic resolution of compound 5 with Pronase. A $250 \mathrm{~mL}$ three necked round-bottomed flask was immersed in a thermostatic oil bath, equipped with a magnetic stirrer and connected to an automatic titration device through the necks (burette, electrode and temperature probe, respectively). The bath temperature was set to $40^{\circ} \mathrm{C}$ and the titrator reservoir was filled with $0.5 \mathrm{M}$ $\mathrm{NaOH}$. In the flask, TRIS base $(75 \mathrm{mg}, 0.6 \mathrm{mmol})$ was dissolved in water $(120 \mathrm{~mL})$ together with Pronase (1.00 g), and the $\mathrm{pH}$ was adjusted to 8 with $1 \mathrm{M} \mathrm{NaOH}$. Compound 5 (1.50 g; $5.2 \mathrm{mmol}$ ) was dissolved in DMSO (12 mL) and dropped to the solution under stirring. The titrator was regulated for keeping the reaction mixture at $\mathrm{pH}=8$, and the data were collected. At fixed intervals, aliquots were taken from the solution and analysed by HPLC [Chiralcel ${ }^{\circledR}$ OD column $(250 \times 4.6$ $\mathrm{mm}), 25^{\circ} \mathrm{C}$, nhexane/2-propanol, 9:1, flow $1 \mathrm{~mL} / \mathrm{min} ; 210 \mathrm{~nm}$.]. When e.e. of substrate 5 was found to be over $99 \%$ (usually around $65-70 \%$ of conversion, after 6-8 days), the titration was switched off and the stirring was interrupted. The reaction mixture was extracted twice with $\mathrm{Et}_{2} \mathrm{O}$. The organic layers were brought together and dried on anhydrous $\mathrm{Na}_{2} \mathrm{SO}_{4}$. The solvent was removed leaving an oily residue corresponding to ester (-)-5 (432 mg, 29\%, e.e. 99\%): $[\alpha]_{\mathrm{D}}{ }^{25}=-36.4$ $\left(c=1\right.$ in $\left.\mathrm{CHCl}_{3}\right)$.

The aqueous layer was acidified to $\mathrm{pH} 3$ with $6 \mathrm{M} \mathrm{HCl}$ and extracted twice with $\mathrm{Et}_{2} \mathrm{O}$. The organic layers were brought together, dried over $\mathrm{Na}_{2} \mathrm{SO}_{4}$ and the solvent was removed. An oily residue was obtained corresponding to the acid (+)-6 (823 mg, $60 \%$, e.e. $\approx 48 \%)$. NMR data of compound 6 are in agreement with those reported in the literature. ${ }^{[20]}$

Recycle of the enantio-enriched acid (+) 6 to racemic 5. Acid (+)-6 (e.e. $\approx 48 \% ; 1 \mathrm{~g}, 3.6 \mathrm{mmol})$ was dissolved in dry $\mathrm{CH}_{2} \mathrm{Cl}_{2}(33 \mathrm{~mL})$ and the solution was cooled to $0{ }^{\circ} \mathrm{C}$. DMAP $(44 \mathrm{mg}, 0.36$ mmol), EtOH (1.5 mL) were added and then DCC (819 mg, $4 \mathrm{mmol})$ dissolved in $\mathrm{CH}_{2} \mathrm{Cl}_{2}(5 \mathrm{~mL})$ was slowly dropped. The reaction was stirred at $25^{\circ} \mathrm{C}$ for $1 \mathrm{~h}$. The solvent was removed. The crude reaction mixture was taken up with $\mathrm{Et}_{2} \mathrm{O}$. The solid was filtered and the crude was purified by column chromatography affording pure ester (+)-5 (618 mg, 56\%).

The enantio-enriched ester (+)-5 (600 mg, $2.08 \mathrm{mmol})$ was dissolved in $\mathrm{CH}_{2} \mathrm{Cl}_{2}(3 \mathrm{~mL})$ and DBU (300 $\mu \mathrm{L}, 2.01 \mathrm{mmol}$ ) was added. The solution was stirred at $25^{\circ} \mathrm{C}$ for $3 \mathrm{~h}$. The reaction was monitored by HPLC [Chiracel OD; nhexane/2-PrOH, 9:1; $1 \mathrm{~mL} / \mathrm{min} ; 210 \mathrm{~nm}$ ]. The organic layer was washed with $0.1 \mathrm{~N} \mathrm{HCl}$ solution $(3 \mathrm{~mL})$. The aqueous layer was extracted with $\mathrm{Et}_{2} \mathrm{O}(3 \times 3$ 
$\mathrm{mL}$ ). The organic layers were brought together and dried over $\mathrm{Na}_{2} \mathrm{SO}_{4}$ affording racemic ester $\mathbf{5}$ in quantitative yield.

Ethyl (R)-1,2,3,4-tetrahydroisoquinolin-4-carboxylates $\cdot \mathrm{CF}_{3} \mathrm{CO}_{2} \mathrm{H}$ (-)4. Enantiopure ester (-)-5 (140 mg, $0.46 \mathrm{mmol})$ was dissolved in dry $\mathrm{CH}_{2} \mathrm{Cl}_{2}(5 \mathrm{~mL})$ and the solution was cooled at $0{ }^{\circ} \mathrm{C}$. $\mathrm{CF}_{3} \mathrm{CO}_{2} \mathrm{H}(0.5 \mathrm{~mL})$ was added and the solution was stirred for $1.5 \mathrm{~h}$ at $25{ }^{\circ} \mathrm{C}$. After solvent evaporation, (-)-4 $\mathrm{CF}_{3} \mathrm{CO}_{2} \mathrm{H}(147.3 \mathrm{mg}$, quantitative yield $)$ was isolated: $[\alpha]_{\mathrm{D}}^{25}=-42.3(c=1$ in MeOH). ${ }^{1} \mathrm{H}$ NMR (MeOD, $\left.200 \mathrm{MHz}\right) \delta=7.55-7.24(\mathrm{~m}, 4 \mathrm{H}), 4.38(\mathrm{~s}, 2 \mathrm{H}), 4.23(\mathrm{q}, J 7.2 \mathrm{~Hz}, 2 \mathrm{H})$, $4.19,3.90,3.52$ (ABX system, $J 13.1,5.2,3.6 \mathrm{~Hz}, 3 \mathrm{H}), 1.27$ (t, $J 7.2 \mathrm{~Hz}, 3 \mathrm{H}$ ); elemental analysis calcd (\%) for $\mathrm{C}_{14} \mathrm{H}_{16} \mathrm{~F}_{3} \mathrm{NO}_{4}$ : C, 52.67; H, 5.05; N, 4.39; found C, 52.19; H, 5.48; N, 3.91 .

Fmoc-( $\boldsymbol{L})$-Ala-(R)- $\boldsymbol{\beta}$-TIC-OEt (-)-8. Fmoc- $L$-Ala $(88.7 \mathrm{mg}, 0.28 \mathrm{mmol})$ was dissolved in $\mathrm{CH}_{2} \mathrm{Cl}_{2}$ (3 mL) and DMF (0.5 mL), the solution was cooled to $0{ }^{\circ} \mathrm{C}$ and $\mathrm{HOBT}(42.3 \mathrm{mg}, 0.31 \mathrm{mmol})$ and EDC $(60.1 \mathrm{mg}, 0.31 \mathrm{mmol})$ were added. The mixture was stirred at $0^{\circ} \mathrm{C}$ for $1 \mathrm{~h}$. Then compound (-)4 (100 mg, $0.31 \mathrm{mmol})$, dissolved in $\mathrm{CH}_{2} \mathrm{Cl}_{2}(0.5 \mathrm{~mL})$ and DIPEA (97.5 $\left.\mu \mathrm{L} 0.56 \mathrm{mmol}\right)$ were added. The reaction mixture was stirred at room temperature for $8 \mathrm{~h}$. A saturated solution of $\mathrm{NaHCO}_{3}(4$ $\mathrm{mL}$ ) was added. The aqueous layer was separated and the organic layer was washed first with a saturated solution of $\mathrm{NH}_{4} \mathrm{Cl}(4 \mathrm{~mL})$ and than with a saturated solution of $\mathrm{NaCl}(4 \mathrm{~mL})$. The organic layer was dried over $\mathrm{Na}_{2} \mathrm{SO}_{4}$. The solvent was removed under reduced pressure and he crude mixture was purified by column chromatography (nhexane/AcOEt, 7:3). Pure compound (-)-8 was obtained as a colourless oil $(130 \mathrm{mg}, 90 \%) .[\alpha]_{\mathrm{D}}{ }^{25}=-11\left(c=1\right.$ in $\left.\mathrm{CDCl}_{3}\right) ;{ }^{1} \mathrm{H}$ NMR $\left(\mathrm{CDCl}_{3}, 300\right.$ $\mathrm{MHz}): \delta$ (mixture of rotamers: 1:1) = $7.76(\mathrm{~d}, J 7.7,2 \mathrm{H}), 7.63-7.60(\mathrm{~m}, 2 \mathrm{H}), 7.42-7.15(\mathrm{~m}, 8 \mathrm{H})$, $6.06(\mathrm{~d}, J 7.1 \mathrm{~Hz}, 0.5 \mathrm{H}), 5.95$ (d, J 7.7 Hz, 0.5H), 5.19, 4.49 (AX system, $J 17.6 \mathrm{~Hz}, 1 \mathrm{H}), 4.96-4.92$ (m, 0.5H), 4.78, 4.67 (AB system, $J 17.7 \mathrm{~Hz}, 1 \mathrm{H}), 4.79-4.62$ (m, 0.5H), 4.38-4.09 (m, 6H), 3.89$3.85(\mathrm{~m}, 1 \mathrm{H}), 3.65-3.53(\mathrm{~m}, 1 \mathrm{H}), 1.42+1.37(\mathrm{~d}, J 6.7 \mathrm{~Hz}, 1.5+1.5 \mathrm{H}), 1.27+1.20(\mathrm{t}, J 7.2,1.5+1.5 \mathrm{H})$; ${ }^{13} \mathrm{C} \mathrm{NMR}\left(\mathrm{CDCl}_{3}, 300 \mathrm{MHz}\right): \delta=14.4$ (14.3), 19.6 (19.5), 42.2, 44.5, 44.7, 47.2, 47.5 (47.4), 61.9 (61.5), 67.2 (67.1), 120.2, 129.5-125.4 (x12), 132.0 (130.8), 132.7 (132.1), 141.5, 144.2 (144.1), 144.3 (144.2), 155.8 (155.6), 171.1, 171.9; MS (ESI): $m / z(\%): 499.2[\mathrm{M}+1]^{+}$; elemental analysis calcd (\%) for $\mathrm{C}_{30} \mathrm{H}_{30} \mathrm{~N}_{2} \mathrm{O}_{5}$ : C, 72.27; H, 6.06; N, 5.62; found C, 71.96; H, 6.39; N, 5.39.

Fmoc-L-Ala-(R)- $\boldsymbol{\beta}$-TIC-OH (-)-9. Dipeptide (-)-8 (110 mg, $0.22 \mathrm{mmol})$ was dissolved in DCE (7 $\mathrm{mL}) . \mathrm{Me}_{3} \mathrm{SnOH}\left(320 \mathrm{mg}, 1.8 \mathrm{mmol}\right.$ ) was added and the mixture was stirred under reflux at $80^{\circ} \mathrm{C}$ for $24 \mathrm{~h}$. The solution was than cooled at room temperature, diluted with $\mathrm{CH}_{2} \mathrm{Cl}_{2}(25 \mathrm{~mL})$ and washed twice with a solution of $\mathrm{KHSO}_{4}(40 \mathrm{~mL}, 0.05 \mathrm{M})$ and then with a saturated solution of $\mathrm{NaCl}(40$ $\mathrm{mL})$. After the separation of the aqueous layer, the organic layer was dried over $\mathrm{Na}_{2} \mathrm{SO}_{4}$. The solvent was removed under reduced pressure and the crude mixture was purified by column chromatography $\left(\mathrm{CH}_{2} \mathrm{Cl}_{2} / \mathrm{MeOH} 20: 1\right)$. Pure compound (-)-9 was isolated as a colourless oil (92 
mg, 89\%). $[\alpha]_{\mathrm{D}}^{25}=-15.4\left(c=1\right.$ in $\left.\mathrm{CDCl}_{3}\right) ;{ }^{1} \mathrm{H}$ NMR $\left(\mathrm{CDCl}_{3}, 300 \mathrm{MHz}\right): \delta$ (mixture of rotamers: $1: 1)=7.80-7.76(\mathrm{~m}, 2 \mathrm{H}), 7.63-7.57(\mathrm{~m}, 2 \mathrm{H}), 7.44-7.17(\mathrm{~m}, 8 \mathrm{H}), 6.31(\mathrm{~d}, J 8.1 \mathrm{~Hz}, 0.5 \mathrm{H}), 6.00(\mathrm{~d}, J$ $7.4 \mathrm{~Hz}, 0.5 \mathrm{H}), 5.27,5.11$ (AB system, $J 17.6 \mathrm{~Hz}, 1 \mathrm{H}), 5.07-4.97$ (m, 0.5H), 4.84, 4.70 (AB system, $J$ 16.6 Hz, 1H), 4.82-4.76 (m, 0.5H), 4.48-4.17 (m, 4H), 3.95-3.88 (m, 1H), 3.60-3.58 (m, 0.5H), $3.36(\mathrm{dd}, J 13.3,3.8,0.5 \mathrm{H}), 3.10-2.10$ (brs, $1 \mathrm{H}), 1.42+1.37(\mathrm{~d}, J 6.7 \mathrm{~Hz}, 1.5+1.5 \mathrm{H})$; ${ }^{13} \mathrm{C} \mathrm{NMR}$ $\left(\mathrm{CDCl}_{3}, 300 \mathrm{MHz}\right): \delta=19.5,42.6,44.0$ (44.4), 44.6 (44.8), 47.1, 44.4, 67.1 (67.2), 120.2, 125.2129.9 (x13), 131.4, 132.6, 141.2, 144.0 (m), 156.1, 173.3, 174.4; MS (ESI): $m / z(\%): 471.2$ $[\mathrm{M}+1]^{+}, 493.3[\mathrm{M}+\mathrm{Na}]^{+}$; elemental analysis calcd $(\%)$ for $\mathrm{C}_{28} \mathrm{H}_{26} \mathrm{~N}_{2} \mathrm{O}_{5}: \mathrm{C}, 71.47 ; \mathrm{H}, 5.57 ; \mathrm{N}, 5.95$; found C, 71.02; H, 5.89; N, 5.54.

Fmoc-L-Ala- $\boldsymbol{\beta}$-TIC- $\boldsymbol{\beta}$-Ala-L-Val-OBn (+)-10. Dipeptide (-)-9 (80 mg, $0.17 \mathrm{mmol})$ was dissolved in $\mathrm{CH}_{2} \mathrm{Cl}_{2}(2 \mathrm{~mL})$. The solution was cooled to $0{ }^{\circ} \mathrm{C}$ and $\mathrm{HOBT}(27.6 \mathrm{mg}, 0.20 \mathrm{mmol})$ and EDC (39.1 mg, $0.20 \mathrm{mmol}$ ) were added. The mixture was stirred at $0^{\circ} \mathrm{C}$ for $1 \mathrm{~h}$. Boc- $\beta$-Ala-L-Val-OBn (7) (51.8 mg, $0.18 \mathrm{mmol})$ was dissolved in $\mathrm{CH}_{2} \mathrm{Cl}_{2}(0.5 \mathrm{~mL})$ and DIPEA (59 $\left.\mu \mathrm{L}, 0.34 \mathrm{mmol}\right)$ was added. The reaction mixture was stirred at $25{ }^{\circ} \mathrm{C}$ for $8 \mathrm{~h}$. The organic layer was washed with a saturated solution of $\mathrm{NaHCO}_{3}(4 \mathrm{~mL})$, saturated solutions of $\mathrm{NH}_{4} \mathrm{Cl}(4 \mathrm{~mL})$, and $\mathrm{NaCl}(4 \mathrm{~mL})$ and then dried over $\mathrm{Na}_{2} \mathrm{SO}_{4}$. The solvent was removed under reduced pressure. The crude mixture was purified by column chromatography (nhexane/AcOEt, 1:0 to 0:1) affording pure (+)-10 (94.4 mg, $76 \%)$. $[\alpha]_{\mathrm{D}}^{25}=+31.6\left(c=1\right.$ in $\left.\mathrm{CDCl}_{3}\right)$; NMR data are reported in Supporting Information; MS (ESI): $m / z(\%): 731.3[\mathrm{M}+1]^{+}$; elemental analysis calcd $(\%)$ for $\mathrm{C}_{43} \mathrm{H}_{46} \mathrm{~N}_{4} \mathrm{O}_{7}: \mathrm{C}, 70.67 ; \mathrm{H}, 6.34 ; \mathrm{N}$, 7.67; found C, 70.41; H, 6.59; N, 7.50.

Synthesis of Fmoc-L-Ala- $\beta$-TIC- $\beta$-Ala-L-Val-OBn (+)-10 and (-)-11. Starting from racemic 4. $\mathrm{AcOH}(500 \mathrm{mg}, 1.88 \mathrm{mmol})$, the mixture of (+)-10 and (-)-11 was obtained using the same reaction conditions described for the transformation of (-)-4 into (+)-10, without separation of intermediates of the $R$ and $S$ series. A crude mixture of diastereoisomeric peptides were obtained in $43 \%$ overall yield $(170 \mathrm{mg})$. It is possible to partially separate compounds (+)-10 and (-)-11 by column chromatography ( $n$ hexane/AcOEt, $1: 0$ to $0: 1$ ).

(-)-11: $[\alpha]_{\mathrm{D}}^{25}=-38.0\left(c=1\right.$ in $\left.\mathrm{CDCl}_{3}\right)$; NMR data are reported in Supporting Information. MS (ESI): $m / z(\%): 731.3[\mathrm{M}+1]^{+}$; elemental analysis calcd (\%) for $\mathrm{C}_{43} \mathrm{H}_{46} \mathrm{~N}_{4} \mathrm{O}_{7}: \mathrm{C}, 70.67 ; \mathrm{H}, 6.34 ; \mathrm{N}, 7.67$; found $\mathrm{C}, 70.35 ; \mathrm{H}, 6.63 ; \mathrm{N}, 7.47$.

ROESY distances determination. ROESY data were collected with roesyph and roesyetgp pulse program with 2048 data points in F2 and 512 data points in F1. For roesy spinlock, 200 ms time was used (16 scans). 
Theoretical calculations. The computational refinement of $\mathbf{1 0}$ and $\mathbf{1 0}$ ' geometries was performed using Amber14 ${ }^{[19]}$ by following the procedure described in the Amber documentation. Charge parameterization of amino acids $\beta$-TIC and $\beta$-Ala and of protecting groups Fmoc, benzyloxy and methoxy was done using the RED method to derive RESP charges which are both conformation and orientation independent, ${ }^{[21]}$ as described previously for other non-natural amino acids. ${ }^{[22]}$ Distance restraints for both 10 and 10' conformations were generated from NOE-derived distances using the "makeDIST_RST" command and peptide $\mathbf{1 0}$ was then constructed using tleap. The ff96 force field, coupled with the Generalized Born model OBC(II) was chosen, ${ }^{[18]}$ accordingly to suggestions reported in the literature by us and by others. ${ }^{[23]}$ Two simulated annealing (SA) cycles, starting from different conformations generated by a random variation of $\varphi, \theta$ and $\psi$ dihedrals, were performed by following this protocol: a) geometry minimization by 500 cycles of steepest descendent followed by 500 cycles of conjugated gradient; b) simulated annealing, for a total of 2000000 steps ( 2 ns of simulation); the system was heated up to $600 \mathrm{~K}$ during the first 500 ps (heat bath coupling constant tautp $=0.4 \mathrm{ps}$ ), then slowly re-cooled to $100 \mathrm{~K}$ from 501 to $180000 \mathrm{ps}$ (tautp $=4.0 \mathrm{ps)}$ and finally to $0 \mathrm{~K}$ with tautp gradually reducing from 1.0 to 0.05 (see Supporting Information for detailed input

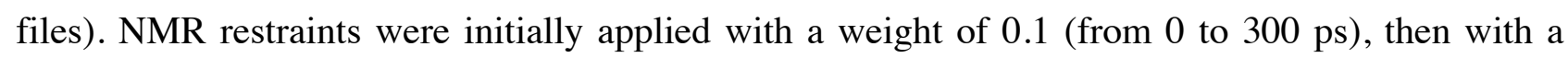
weight of 1 . Langevin dynamics $(n t t=3)$ with a collision frequency of $1.0 \mathrm{ps}^{-1}$ were used here, as well as in simulation described below.

REMD simulations ${ }^{24}$ of peptides $\mathbf{1 0}$ and $\mathbf{m 1 0}$ were performed accordingly to a protocol described previously. ${ }^{[4 a, 23 a]}$ Briefly, simulations were conducted using the ff96 force field, coupled with the Generalized Born model OBC(II). A temperature range spanning from 260.0 and $591.4 \mathrm{~K}$ was used to run 12 replica of $400 \mathrm{~ns}$ each (see Supporting Information). Convergence was evaluated by performing on the $300 \mathrm{~K}$ trajectory a cluster analysis every $50 \mathrm{ps}$. The simulation was considered converged when the population of the two principal clusters differed less than $5 \%$ between the two $50 \mathrm{~ns}$ batches. Both simulations (10 and m10) were converged after 300 ns. Cluster analysis was made by using cpptraj, sampling one of every four frames, using the average-linkage algorithm and the pairwise mass-weighted RMSD on backbone heavy atoms.

\section{Supporting Information}

Further information on enzymatic resolution of ester 5. General synthesis of dipeptide 7. ${ }^{1} \mathrm{H}$ NMR studies at variable temperature for (-)-9. NMR data for peptides (+)-10 and (-)-11. Determination of the stereochemistry of $R$ - $\beta$-TIC in peptide (+)-10 through ${ }^{1} \mathrm{H}$ NMR data. NMR spectra for compounds 1,3,4,5,8-11. Additional computational details. 


\section{References}

[1] a) K. R. Rajashankar, S. Ramakumar, Protein Sci. 1996, 5, 932-946; b) L. E. Donate, S. D. Rufino, L. H. Canard, T. L. Blundell, Protein Sci. 1996, 5, 2600-2616; c) G. D. Rose, L. M. Gierasch, J. A. Smith, Adv. Protein Chem. 1985, 37, 1-109.

[2] a) Y. Zhu, T. Li, D. Li, Y. Zhang, W. Xiong, J. Sun, Z. Tang, G. Chen, Amino Acids 2012, 42, 1749-1755; b) A. Bax, J. Biomol. NMR 2012, 52, 211-232. c) P. Petersen, C. Lundegaard, T. N. Petersen, PLoS One 2010, 5, e15079; d) B. Dasgupta, P. Chakrabarti, BMC Struct. Biol. 2008, 8, 39; e) A. J. P. Fuchs. A. Alix, Proteins Struct. Funct. Bioinform. 2005, 59, 828-839. f) H. Kaur, G. P. S. Raghava, Protein Sci. 2003, 12, 627-634; g) S. Datta, N. Shamala, A. Banerjee, A. Pramanik, S. Bhattacharjya, P. Balaram J. Am. Chem. Soc. 1997, 119, 9246-9251; h) J. S. Richardson, Adv. Protein Chem. 1981, 34, 167-339.

[3] a) A. A. Fuller, D. Du, F. Liu, F.; J. E. Davoren, G. Bhabha, G. Kroon, D. A. Case, H. J. Dyson, E. T. Powers, P. Wipf, M. Gruebele, J. W. Kelly, PNAS 2009, 106, 11067-11072; b) S. Oishi, K. Miyamoto, A. Niida, M. Yamamoto, K. Ajito, H. Tamamura, A. Otaka, Y. Kuroda, A. Asai, N. Fujii, Tetrahedron 2006, 62, 1416-1424; c) A. J. Souers, J. A. Ellman, Tetrahedron 2001, 57, 74317448; d) Y. J. Chung, B. R. Huck, L. A. Christianson, H. E. Stanger, S. Krauthauser, D. R. Powell, S. H. Gellman, J. Am. Chem. Soc. 2000, 12, 3995-4004. e) B. R. Huck, J. D. Fisk, S. H. Gellman Org. Lett. 2000, 2, 2607-2610; f) R. R. Gardner, G. B. Liang, S. H. Gellman J. Am. Chem. Soc. 1999, 121, 1806-1816; g) Y. J. Chung, L. A. Christianson, H. E. Stanger, D. R. Powell, S. H. Gellman, J. Am. Chem. Soc. 1998, 120, 10555-10556; h) P. Wipf, T. C. Henninger, S. J. Geib, J. Org. Chem. 1998, 63, 6088-6089; i) C. N. Nesloney, J. W. Kelly, Bioorg. Med. Chem. 1996, 4, 739766; j) U. Nagai, K. Sato Tetrahedron Lett. 1995, 26, 647-650. k) J. P. Schneider, J. W. Kelly, Chem. Rev. 1995, 95, 2169-2187; 1) K. J. Tsang, H. Diaz, N. Graciani, J. W. Kelly, J. Am. Chem. Soc. 1994, 116, 3988-4005; m) H. Diaz, K. J. Tsang, D. Choo, J. R. Espina, J. W. Kelly, J. Am. Chem. Soc. 1993, 115, 3790-3791; n) H. Diaz, J. R. Espina J. W. Kelly, J. Am. Chem. Soc. 1992, $114,8316-8318$.

[4] a) S. Pellegrino, N. Tonali, E. Erba, J. Kaffy, M. Taverna, A. Contini, M. Taylor, D. Allsop, M. L. Gelmi, S. Ongeri, Chem. Sci 2016, 8, 1295-1302; b) E. Ko, A. Raghuraman, L. M. Perez, T. R. Ioerger, K. J. Burgess, J. Am. Chem. Soc. 2013, 135, 167-173.

[5] P. Chakrabarti, R. Bhattacharyya, Prog. Biophys. Mol. Biol. 2007, 95, 83-137.

[6] a) S. Pellegrino, A. Bonetti, F. Clerici, A. Contini, A. Moretto, R. Soave, M. L. Gelmi, J. Org. Chem., 2015, 80, 5507-5516; b) A. Ruffoni, A. Contini, R. Soave, L. Lo Presti, I. Esposto, I. Maffucci, D. Nava, S. Pellegrino, M. L. Gelmi, F. Clerici, RSC Adv, 2015, 5, 32643-32656; c) S. 
Pellegrino, A. Contini, M. L. Gelmi, L. Lo Presti, R. Soave, E. Erba, J. Org. Chem., 2014, 79, 3094-3102; d) A. Bonetti, F. Clerici, F. Foschi, D. Nava, S. Pellegrino, M. Penso, R. Soave, M. L. Gelmi, Eur. J. Org. Chem., 2014, 15, 3203-3209; e) S. Pellegrino, A. Contini, F. Clerici, A. Gori, D. Nava, M. L. Gelmi, Chemistry-Eur. J. 2012, 18, 8705-8715; f) M. Penso, F. Foschi, S.Pellegrino, A. Testa, M. L. Gelmi J. Org. Chem. 2012, 77, 3454-3461; g) A. Ruffoni, A. Casoni, S. Pellegrino, M. L. Gelmi, R. Soave, F. Clerici, Tetrahedron, 2012, 68, 1951-1962; h) F. Gassa, A. Contini, G. Fontana, S. Pellegrino, M. L. Gelmi, J. Org. Chem., 2010, 75, 7099-7106; i) S. Pellegrino, F. Clerici, M. L. Gelmi, Tetrahedron 2008, 64, 5657-5665; j) M. L. Gelmi, C. Cattaneo, S. Pellegrino, F. Clerici, M. Montali, C. Martini J. Org. Chem. 2007, 72, 9811-9814; k) C. Cabrele, F. Clerici, M. L. Gelmi, R. Gandolfi, F. Molinari, S. Pellegrino, Tetrahedron, 2006, 62, 3502-3508.

[7] a) A. Gori, C.-I A. Wang, P. J. Harvey, K. J. Rosengren, R. F. Bhola, M. L. Gelmi, R. Longhi, M. J. Christie, R. J. Lewis, P. F. Alewood, A. Brust, Angew. Chem. Int. Ed. 2015, 54, 1361-1364; i) S. Pellegrino, N. Ferri, N. Colombo, E. Cremona, A. Corsini, R. Fanelli, M. L. Gelmi, C. Cabrele, Bioorg. Med. Chem. Lett., 2009, 19, 6298-6302;

[8] G. Valle, W. M. Kazmierski, M. Crisma, G. M. Bonora, C. Toniolo, V. J. Hruby Int. J. Pept. Prot. Resch. 1992, 40, 222-232.

[9] Bernabeu, M. C.; Diaz, J. L.; Jimenez, O.; Lavilla, R. Synthetic Comm. 2004, 1, 137-149.

[10] a) P. Hoyos, V. Pace, M. J. Hernaiz, A. R. Alcantara, A. R. Curr. Green Chem. 2014, 1, 155181; b) A. Wells, H.-P. Meyer, Chem. Cat. Chem. 2014, 6, 918-920.

[11] a) A. Liljeblad, L. T. Kanerva, Tetrahedron 2006, 62, 5831-5854; b) A. Berkessel, I. Jurkiewicz, R. Mohan, Chem. Cat. Chem. 2011, 3, 319-330; c) A. Liljeblad, H.-M. Kavenius, P. Tähtinen, L. T. Kanerva, Tetrahedron: Asymmetry 2007, 18, 181-191.

[12] a) C. Cabrele, T.A. Martinek, O. Reiser, Ł. Berlicki, J. Med. Chem. 2014, 57, 9718-9739; b) M. A. Gelman, S. H. Gellman in Enantioselective Synthesis of $\beta$-Amino Acids, Second Edition (eds E. Juaristi and V. A. Soloshonok), John Wiley \& Sons, Inc., Hoboken, NJ, USA. doi: $10.1002 / 0471698482 . \operatorname{ch} 22$

[13] J. R. Martinelli, D. A. Watson, D. M. M. Freckmann, T. E. Barder, S. L. Buchwald, J. Org. Chem., 2008, 73, 7102-7107.

[14] S. Shotani, T. Hori, K. Mitsuhashi, Chem. Pharm. Bull. 1967, 15, 88-93.

[15] D. Tessaro, Cascade Biocatalysis, 2014, 179-198.

[16] P. D'Arrigo, L. Cerioli, S. Servi, F. Viani, D. Tessaro, Catal. Sci. Techol. 2012, 2, 1606-1616.

[17] K. C. Nicolaou, A. A. Estrada, M. Zak, S. H. Lee, B. S. Safina, Angew. Chem. Int. Ed. 2005, 44, 1378-1382.

[18] A. Onufriev, D. Bashford, D. A. Case, Proteins 2004, 55, 383-394. 
[19] D. A. Case, V. Babin, J. T. Berryman, R. M. Betz, Q. Cai, D. S. Cerutti, T. E. Cheatham, T. A. Darden, R. E. Duke, H. Gohlke, A. W. Goetz, S. Gusarov, N. Homeyer, P. Janowski, J. Kaus, I. Kolossváry, A. Kovalenko, T. S. Lee, S. LeGrand, T. Luchko, R. Luo, B. Madej, K. M. Merz, F. Paesani, D. R. Roe, A. Roitberg, C. Sagui, R. Salomon-Ferrer, G. Seabra, C. L. Simmerling, W. Smith, J. Swails, Walker, J. Wang, R. M. Wolf, X. Wu, P. A. Kollman, Amber 14. University of California, San Francisco, 2014.

[20] A. Bonetti, E. Beccalli, A. Caselli, F. Clerici, S. Pellegrino, M. L. Gelmi, Chem. Eur. J. 2015, $21,1692-1703$.

[21] F.-Y. Dupradeau, A. Pigache, T. Zaffran, C. Savineau, R. Lelong, N. Grivel, D. Lelong, W. Rosanski, P. Cieplak, Phys. Chem. Chem. Phys. 2010, 12, 7821-7839.

[22] a) I. Maffucci, S. Pellegrino, J. Clayden, A. Contini, J. Phys. Chem. B 2015, 119, 1350-1361. b) I. Maffucci, J. Clayden, A. Contini, J. Phys. Chem. B 2015, 119, 14003-14013.

[23] a) I. Maffucci, A. Contini, J. Chem. Theory Comput., 2016, 12, 714-727. b) M. K. Robinson, J. I. Monroe, M. S. Shell, J. Chem. Theory Comput. 2016, 12, 5631-5642. c) M. S. Shell, R. Ritterson, K. A. Dill, J. Phys. Chem. B. 2008, 112, 6878-6886.

[24] Y. Sugita, Y. Okamoto Chem. Phys. Lett. 1999, 314, 141-151. 